This item was submitted to Loughborough's Research Repository by the author.

Items in Figshare are protected by copyright, with all rights reserved, unless otherwise indicated.

\title{
Warm glow or extra charge? The ambivalent effect of corporate social responsibility activities on customers' perceived price fairness
}

\section{PLEASE CITE THE PUBLISHED VERSION}

https://doi.org/10.1509/jm.14.0389

\section{PUBLISHER}

(c) American Marketing Association

\section{VERSION}

AM (Accepted Manuscript)

\section{PUBLISHER STATEMENT}

This work is made available according to the conditions of the Creative Commons Attribution-NonCommercialNoDerivatives 4.0 International (CC BY-NC-ND 4.0) licence. Full details of this licence are available at: https://creativecommons.org/licenses/by-nc-nd/4.0/

\section{LICENCE}

CC BY-NC-ND 4.0

\section{REPOSITORY RECORD}

Habel, Johannes, Laura M. Schons, Sascha Alavi, and Jan Wieseke. 2019. "Warm Glow or Extra Charge? the Ambivalent Effect of Corporate Social Responsibility Activities on Customers' Perceived Price Fairness". figshare. https://hdl.handle.net/2134/33438. 


\title{
Warm Glow or Extra Charge? The Ambivalent Effect of Corporate Social Responsibility Activities on Customers’ Perceived Price Fairness
}

\begin{abstract}
Prior research has firmly established that consumers draw benefits from a firm's engagement in corporate social responsibility (CSR), especially the feeling of a "warm glow.” These benefits positively affect several desirable outcomes, such as willingness to pay or customer loyalty. The authors propose that consumers do not blindly perceive benefits from a firm's CSR engagement, but tend to suspect that a firm’s prices include a mark-up to finance the CSR engagement. Taking customers' benefit perceptions and price mark-up inferences into account, the authors suggest that CSR engagement has mixed effects on consumers' evaluation of price fairness and, thus, subsequent outcomes such as customer loyalty. The authors conducted one qualitative study and four quantitative studies leveraging longitudinal field and experimental data of over 4,000 customers showing that customers in fact infer CSR price mark-ups, entailing mixed effects of firms' CSR engagement on price fairness. The authors find that perception critically depends on customers' CSR attributions and explore the underlying psychological mechanisms. They propose communication strategies to optimize the effect of CSR engagement on perceived price fairness.
\end{abstract}

Keywords: corporate social responsibility; price fairness; cost perceptions; behavioral pricing. 
Firms frequently engage in corporate social responsibility (CSR) as they seek to be perceived as a fair market actor (Campbell 2007). From customers’ perspective, a key manifestation of a firm’s fairness in the exchange relationship is price fairness (Guo 2015; Xia, Monroe, and Cox 2004). However, the impact of CSR activities on customers’ perceptions of price fairness has not previously been explored. Prior research might lead to the assumption of a positive association of CSR engagement and perceived price fairness (e.g., Du, Bhattacharya, and Sen 2007; De Pelsmacker, Driesen, and Rayp 2005; Lichtenstein, Drumright, and Braig 2004), since the “warm glow” experienced through helping others adds to customers' benefits from the relationship with the firm (Andrews et al. 2014).

However, we argue that despite its intuitive appeal, this logic may be misleading, as customers do not judge price fairness solely on the basis of the benefits they obtain. Instead, prior research established that customers weigh the benefits against costs induced by a purchase (Homans 1961; Xia, Monroe, and Cox 2004). Hence, how CSR actions relate to perceived price fairness depends not only on customers" "warm glow” but also on the question of how CSR engagement affects customers' cost perceptions. Specifically, if customers infer that a company charges higher prices to finance its CSR engagement, their perception of price fairness may not improve and may even deteriorate indicating a negative effect of CSR on price fairness.

Anecdotal evidence confirms that customers may consider CSR price mark-ups by viewing firms "to pass on responsibility and cost for sustainability initiatives down the supply chain whilst taking the credit” (CorporateWatch 2006, p. 16). Similarly, Chandler and Werther (2014, p. 166) indicate that firms might "pass [CSR] cost increases on to their customers in the form of higher prices”. In this respect, a recent Forbes article claims that "consumers and the public expect sustainability as a baseline condition of business [but] they don't expect to pay for it” (Unruh 2011). 
To our best knowledge, the notion that CSR engagement may induce customers to infer a cost burden has not been the subject of previous marketing research. Consequently, prior marketing research cannot fully explain the CSR-price fairness linkage, and how firms’ CSR activities influence the perception of price fairness remains unclear. Web Appendix W1 illustrates the research void addressed in this study.

This prevailing unclarity is not only troublesome for marketing research but also problematic for managerial practice, since firms lack guidance on how to effectively manage the price-related consequences of their CSR. If being perceived as socially caring comes at the expense of a firm's price image, the firm will face a goal conflict, requiring careful management of the trade-off between being perceived as fair in terms of social engagement and fair in terms of price. Hence, examining the CSR-price fairness linkage is highly relevant to the effectiveness of firms’ strategies to manage price-related consequences of their social activities.

In light of the strong theoretical and practical significance, we explore in detail the relationship between firms’ CSR engagement and customer perceptions of price fairness as well as the underlying psychological mechanisms with a particular focus on customers' perceptions of a price mark-up arising from CSR activities. Hereby, we define CSR engagement as the level to which customers perceive a firm to engage in "actions that appear to further some social good, beyond the interests of the firm and that which is required by law" (McWilliams and Siegel 2001, p. 117). Moreover, we develop and verify CSR communication strategies to optimize the effect of firms’ social activities on perceived price fairness. To achieve these research goals, we devised one qualitative interview study and four large-scale quantitative studies comprising experimental and field data from over 4,000 customers. Figure 1 gives an overview of the four studies and the conceptual framework, and Web Appendices W7 and W8 describe two further experiments. 
Drawing on insights from the interviews, Study 1 examines the effect of firms’ CSR engagement on perceived price fairness moderated by customers’ intrinsic CSR attribution. Results reveal that CSR engagement increases perceptions of price fairness for customers who attribute the engagement to intrinsic firm motives, but substantially decreases price fairness otherwise. Study 2 assesses whether this finding of Study 1 can be explained in terms of customers’ perceived benefit and perceived price mark-up arising from CSR engagement. In Study 3 we advance the understanding of the mechanisms responsible for the effects of firm CSR engagement on perceived price fairness by accounting for two different types of CSR (i.e., business process and philanthropic CSR) and customers’ resulting inferences regarding firms’ CSR costs. We differentiate between the perceived level of firm CSR costs and the perceived type of firm CSR costs.

A key insight that emerged across Studies 1 to 3 is that in the case of customers' extrinsic CSR attribution, a firm’s CSR engagement may afflict price fairness perceptions via customers’ perceived price mark-up. To remedy this detrimental effect and provide actionable guidance to firms, in Study 4 we develop and empirically verify CSR cost communication strategies. Results of a scenario-based experiment show that framing firms' CSR spending as drawing from top management salaries, advertising budgets, or company profits constitutes a viable strategy to counter the potentially harmful effects. Insert Figure 1 about here

As the first paper to holistically explore the relationship between CSR engagement and price fairness perceptions this investigation makes four meaningful contributions to the marketing literature. First, prior marketing research has omitted to examine whether a firm’s CSR engagement may foster not only customers' benefit perceptions but also their cost perceptions in the form of a price mark-up. Hence, our primary contribution to marketing research is the 
introduction of customers' CSR price mark-up perceptions indicating a negative effect of firms' CSR engagement on price fairness and subsequent customer outcomes. Consequently, we find evidence that CSR engagement exhibits mixed effects on perceived price fairness via customers’ perceived benefit, delineating the positive effect, and perceived costs, delineating the negative effect. Second, we add knowledge to marketing research by clarifying that the mixed effects of firms’ CSR engagement on perceived price fairness are strongly contingent on customers’ intrinsic CSR attribution. For high levels of intrinsic CSR attribution the positive effect of CSR engagement on perceived price fairness seems to prevail, whereas for low levels of intrinsic CSR attributions the negative effect reigns. In this respect, our work is similar to Forehand and Grier (2003) as we both focus on the interactive effect of firm CSR engagement and customer attributions on customer outcome variables. However, our studies extend Forehand and Grier’s findings as we show that customers do not only derive benefits from a company’s CSR engagement but also infer firm costs that they expect to be financed through price mark-ups. Hereby, we focus on elucidating customers’ cost-related psychological mechanisms concerning the CSR-price fairness linkage while Forehand and Grier (2003) investigate the influence of firms’ publicly stated CSR motives on customer skepticism. Third, we make an essential contribution to CSR research in general. Recently, researchers have stated that "there seems to be a lack of understanding of the underlying mechanisms linking CSR with outcomes” (Aguinis and Glavas 2011, p. 953), with only 7\% of CSR articles focusing on mediation effects. We broaden the knowledge in this research stream by introducing customers' CSR cost-related inferential mechanisms. 


\section{Hypotheses Development: Examining the CSR-Price Fairness Linkage}

\section{Distributive Justice as the Conceptual Basis of Price Fairness}

We define price fairness as “a consumer's subjective sense of a price as right, just, or legitimate versus wrong, unjust, or illegitimate” (Campbell 2007, p. 261). On the most elementary level customers' assessment of distributive price fairness rests on the concept of distributive justice (Homans 1961), which is a cornerstone of social exchange theory (e.g., Blau 1964; Thibaut and Kelley 1959). According to social exchange theory, customers perceive an exchange relationship as fair if the outputs from the relationship at least equal the investment into the relationship (Homans 1961). In the context of price fairness, customers assess a product's price as fair if their perceived benefit from the product meets or exceeds their perceived purchase costs (Xia, Monroe, and Cox 2004).

Adopting the concept of distributive justice as our guiding theory, we base our conceptualization on the notion that CSR engagement potentially affects customers' benefit-cost comparison. In particular, knowing that the money they spend supports good causes customers might perceive an added value (i.e., a "warm glow”) from purchasing a product. As a result, their perceived benefit-cost ratio and hence their perceived price fairness may improve. In contrast, customers might have perceptions of elevated product costs, believing that prices might be lower if a company did not invest part of its revenue in CSR activities. Consequently, customers’ perceived benefit-cost ratio and hence perception of price fairness may deteriorate.

\section{Distinguishing Price Fairness from Related Price Perception Constructs}

The role of price fairness in price information processing. Perceived price fairness constitutes the core dependent variable in our conceptual framework. In what follows, to substantiate its eligibility and focal role in our model, we distinguish price fairness from related constructs in customers’ price perception. To this end, we rely on the price information processing model 
firmly established by behavioral pricing research (Jacoby and Olson 1977; Niedrich, Sharma, and Wedell 2001; Dodds, Monroe, and Grewal 1991). According to this model, customers process prices in four steps: (1) perception of objective price, (2) formation of subjective price, (3) price evaluation, and (4) price-related behavior. To elaborate, in the first step customers observe and decode the price stimulus. In the second step, customers form a subjective understanding of the price by assessing their perceived sacrifice, i.e., the monetary loss they suffer when paying the price (Zeithaml 1988). The third step of the price information processing model is characterized by an integration of customers' perceived sacrifice with additional informational inputs (Jacoby and Olson 1977) in order to evaluate the price stimulus more comprehensively. Hereby, behavioral pricing research viewed customers’ perceived quality from the transaction as an important additional input to the price evaluation (Zeithaml 1988). Perceived quality reflects customers’ assessment of the performance of product attributes (Sweeney and Soutar 2001). Specifically, customers engage in a mental trade-off weighing perceived price sacrifice against benefits such as perceived product quality to form a price evaluation, resulting in customers’ perception of a product’s price-value ratio (Sweeney and Soutar 2001; Zeithaml 1988).

Importantly, customers’ perceived price fairness likewise belongs to the price evaluation phase as it comprises a weighing of perceived benefits and perceived costs (i.e., perceived sacrifice). While both price-value ratio and price fairness represent price evaluations and hence imply benefit-costs trade-offs, the key difference between these constructs pertains to the strong influence of social norms on price fairness formation (Maxwell 2002). More specifically, when judging a firm's price fairness customers do not only account for the economic trade-off of benefits and costs (as they do for price-value ratio), but additionally factor in whether the company adheres to commonly accepted fairness norms. For instance, derived from the dual entitlement principle, if a firm charges high prices owing to high costs, customers may judge the 
firm’s price-value ratio as low, but customers may still perceive price fairness as high because charging higher prices in the face of higher costs may be socially accepted (Kahneman, Knetsch, and Thaler 1986). As Maxwell (2002, p. 193) puts it: “they [customers] may judge the economic acceptability of the price magnitude in relation to their own self-interest, but at the same time they judge the social acceptability of the price in relation to community standards or rules”.

Eventually, in the fourth step, customers’ price evaluation constitutes a key influence on their price-related behaviors or behavioral intentions. Hereby, behavioral pricing research strongly focused on the analysis of customers’ willingness to pay (WTP) as a key behavioral intention (e.g., Wertenbroch and Skiera 2002). On the basis of the price information processing model price fairness constitutes a predictor of customers’ WTP.

Motivation for selecting price fairness as focal outcome. Having differentiated perceived price fairness from related constructs such as perceived sacrifice, perceived quality, perceived price--value ratio and WTP (Zeithaml 1988), we now elaborate on our motivation for selecting perceived price fairness as the key dependent variable in our conceptual model. We selected perceived price fairness as the key dependent variable instead of alternative price-related variables such as WTP for three reasons: First, CSR engagement and perceived price fairness exhibit a very high theoretical fit as both concepts are similarly rooted in the fundamental social norms of equity and reciprocity prescribed by social exchange theory (Gouldner 1960). That is, both, a firm's social engagement and perceived price fairness, reflect the extent to which the firm strives to achieve equity in the exchange relationship with its key stakeholders. Second, our study focuses on customers' inferences of price mark-ups caused by CSR engagement, which have been neglected in previous research, as well as customers' perceived CSR benefits. According to the concept of distributive justice, weighing costs—-such as an elevated price-and benefits is the central process leading to evaluations of price fairness (Xia, Monroe, and Cox 2004) which 
underlines the eligibility and, in fact, necessity of perceived price fairness in our model. In their seminal work on interpersonal equity in marketing Oliver and Swan (1989) emphasize the need to clearly distinguish between equity-based variables reflecting a cost-benefit ratio with variables that comprise costs or benefit perceptions only such as perceived quality or perceived sacrifice. Third, behavioral pricing research prescribes that WTP constitutes an outcome of perceived price fairness because the latter represents an evaluation of price which induces subsequent pricerelated behavioral intentions such as WTP (Zeithaml 1984). Confirming this notion, Thaler (1985) states that price fairness is a key determinant of WTP. Simultaneously, prior research on price information processing clarifies that perceived quality and perceived sacrifice represent predictors of price fairness. Consequently, when conceptualizing a fine-grained view of the effects of CSR engagement on customers’ perceived CSR benefits and costs, neither perceived quality and perceived sacrifice nor WTP are sensible dependent variables. Instead, focusing on perceived price fairness as a construct that balances customers' benefit and cost perception and reflects social norms seems reasonable regarding our research goals. Importantly, while we focus on perceived price fairness in our conceptual model, we validate our results for perceived sacrifice, quality, price-value ratio, and the WTP-related construct willingness to pay more (see Table 3) to lend additional support to our conceptualization.

\section{The Effect of CSR Engagement on Perceived Price Fairness}

In summary, theoretical considerations based on the distributive justice concept suggest that CSR engagement may exert mixed effects on perceived price fairness via CSR benefit and price markup perceptions. We argue that whether the positive or negative effect prevails depends on customers’ specific inferences regarding a company’s CSR engagement. To gain first insights into the CSR engagement-perceived price fairness linkage, we conducted three focus groups with four to six participants in each group. Web Appendix W2 provides information on the 
methodological details and the sample composition of the focus-group study. In the following section, we present the results of this preliminary focus group study and also, drawing on existing literature, derive formal research hypotheses.

Perceived benefits of CSR engagement. All focus group participants acknowledged clear benefits of CSR engagement for customers. In their eyes, these benefits range from more healthy, organic products to the warm glow they feel when purchasing fair trade products or products from companies that engage in good deeds. For instance, respondent B noted: “For me personally, a labeled fairly traded or ecologically produced product definitely has a higher benefit.” Respondent Q elaborated: “If I had to decide between two products, and I could clearly see how sustainable or socially responsible both products are, I would most probably choose the higher rated product. Because it is worth it.” How do these benefit perceptions translate into price fairness? As discussed above, customers consider prices to be fair if their perceived benefit from purchasing products meets or exceeds their perceived costs (Homans 1961; Xia, Monroe, and Cox 2004). Hence, if CSR engagement increases perceived benefit, customers may evaluate the price level as fairer.

Perceived costs of CSR engagement. In all three focus groups, participants brought up and critically discussed the question of costs of CSR engagement and their implications for a company's pricing. Participants agreed that they believed that some companies who engage in CSR activities pass along the resulting costs to their customers in the form of increased prices. For instance, respondent G asserted: "I really do think the additional costs for CSR are compensated by charging higher prices.” Similarly, Respondent F noted: “I think it is very complicated because the customer does not know which proportion of the price is really due to CSR investments.” 
Again, the concept of distributive justice helps to explain how such perceptions translate into price fairness. In particular, if customers believe that CSR engagement leads to higher prices, their perceived benefit-to-cost ratio from purchasing products may drop, leading customers to evaluate prices as less fair. Our focus group interviews support this notion. For instance, respondent A stated: "If they have spare money, they should do something good with it. But if it means that CSR investments have to be compensated by higher prices for us customers, I am clearly against that.” Furthermore, respondent K explained: "I think it is just plain unfair if a company charges higher prices to support social causes.”

As outlined above, CSR engagement potentially increases both the benefits and the costs customers associate with products, leading to opposing indirect effects of CSR engagement on price fairness. We argue that the strengths of these effects depend on customers' perceptions of the CSR engagement. In other words, under certain circumstances the positive effect of CSR engagement on perceived price fairness via benefit perceptions might prevail, while under other circumstances the negative effect via price mark-up perceptions might prevail. We elaborate on such a contingency in the following section.

Moderating effect of CSR attribution. We theorize that the effect of CSR engagement on perceived price fairness is moderated by customers’ attributions of a company’s motives for engaging in a social cause. In particular, we propose that customers’ perceived price fairness is more positively affected by CSR engagement if the company appears to be intrinsically motivated and more negatively affected if this is not the case. Many studies have empirically observed that customers make assumptions about a firm’s underlying motives for CSR engagement and that these beliefs lead to observable outcomes on a behavioral level (Ellen, Webb, and Mohr 2006; Webb and Mohr 1998). Attribution theory is typically employed to understand underlying psychological mechanisms (Kelley 1967). The literature on customers’ 
attributions of a company's CSR effort mainly distinguishes between intrinsic and extrinsic attributions of the company's motives for a certain CSR commitment (Du, Bhattacharya, and Sen 2010). In making extrinsic attributions, customers primarily infer strategic or financial motives for a company's involvement in a CSR activity whereas in making intrinsic attributions they perceive the firm to have altruistic, honest motives (Forehand and Grier 2003; Becker-Olsen, Cudmore, and Hill 2006). Building on this prior research, we propose that intrinsic CSR attribution moderates the indirect effects of firm CSR engagement on perceived price fairness via both perceived CSR benefit and perceived CSR price mark-up.

Warm glow path. First, regarding the indirect effect via perceived CSR benefit, we argue that the positive effect of perceived CSR benefit on perceived price fairness is more pronounced the more customers perceive firms' CSR engagement to be intrinsically motivated—a prediction derived from the concept of distributive justice, which suggests that CSR engagement creates an emotional value for customers which improves customers' benefit-cost ratio and hence perceived price fairness. However, we argue that the extent to which this incorporation of emotional value takes place depends on customers' attribution of a firm's CSR engagement. If customers perceive engagement to arise from self-serving rather than intrinsic motives, they may doubt the authenticity of the engagement and thus be uncertain of their benefit from the CSR engagement (Barone et al. 2000). The more uncertain customers feel about their CSR benefit, the less weight they may place on this benefit in their price fairness judgments.

Extra charge path. Second, as to the indirect effect via perceived CSR price mark-up, we argue that the positive effect of a firm's CSR engagement on perceived CSR price mark-up is less pronounced the more customers perceive a firm's engagement to be intrinsically motivated. When customers attribute CSR engagement to intrinsic motivation and thus to altruism, they should be likely to infer that the company also acts altruistically in financing its CSR engagement 
to form consistent inferences (Uleman et al. 2008). More specifically, customers should be less likely to suppose that the firm marks up prices to cover its CSR costs since this behavior is not altruistic and thus conflicts with the firm's altruistic CSR engagement. In contrast, if customers conclude that a firm has self-serving goals underlying its CSR engagement, they should be more likely to infer that the company is also acting in a self-serving manner by financing its CSR engagement by passing the costs on to the customer.

Based on the above reasoning, we derive three formal hypotheses. The first of these hypotheses refers to the moderated overall effect of CSR engagement on perceived price fairness without taking into account customers’ perceived benefit and price mark-up as mediators:

$\mathrm{H}_{1}$ : The overall effect of firm CSR engagement on customers' perceived price fairness is more positive for high levels of intrinsic attributions and less positive for low levels of intrinsic attributions.

The second and third hypotheses refer to the moderated, indirect effects of CSR engagement on perceived price fairness via our two hypothesized mediators, i.e., customers’ perceived CSR benefit and price mark-up. We hypothesize:

$\mathrm{H}_{2 \mathrm{a}}$ : The more customers attribute the CSR engagement to intrinsic motives, the greater the positive indirect effect of firm CSR engagement on perceived price fairness via perceived CSR benefit. This holds as intrinsic CSR attribution positively moderates the effect of perceived CSR benefit on perceived price fairness.

$\mathrm{H}_{2 \mathrm{~b}}$ : The less customers attribute CSR engagement to intrinsic motives, the greater the negative indirect effect of firm CSR engagement on perceived price fairness via perceived CSR price mark-up. This holds as intrinsic CSR attribution negatively moderates the effect of CSR engagement on perceived CSR price mark-up.

\section{Firm CSR Costs as the Key Inferential Mechanism of the CSR-Price Fairness Linkage}

To generate a more profound understanding of the CSR-price fairness linkage, we delve more deeply into the psychological mechanisms responsible for our predictions in $\mathrm{H}_{1}$ through $\mathrm{H}_{2 \mathrm{~b}}$. We argue that the mechanism responsible for the influence of firms' CSR engagement on customers' perceived price fairness can be explained in terms of customers' inferences of firms’ CSR costs. 
We differentiate between the perceived level of costs and the type of costs. The distinction between level and type of firm CSR cost builds on seminal work on signaling theory in marketing (Kirmani and Rao 2000), which suggests that firm costs may be conceived of as signals to the customer to overcome information asymmetries (see also Ippolito 1990; Erdem and Swait 1998). We argue that the extent of firms' CSR engagement fosters perceptions of the level of firm CSR costs, while customers' attributions of CSR engagement to intrinsic or extrinsic motivation are associated with the perceived type of firm CSR costs. Hereby, we regard the type of CSR costs as the extent to which customers perceive CSR costs as promotional costs (Yoon, Gürhan-Canli, and Schwarz 2006). Furthermore, we suggest that the interactive effect of the perceived level and type of firm CSR costs needs to be considered when exploring the indirect effects of firms' CSR engagement on perceived price fairness. In what follows, we detail our reasoning on the perceived level and type of firm CSR costs as the key inferential mechanisms underlying the CSR engagement-perceived price fairness relationship.

Perceived level of firm CSR costs. Applying the logic of Kirmani and Rao’s (2000) cost signaling framework, we argue that the stronger a firm’s CSR engagement the more likely customers should be to infer high levels of firm CSR costs which in turn increase both customers' perceived CSR benefit as well as CSR price mark-up. To elaborate, if customers perceive a firm to be highly engaged in CSR, they should tend to infer high CSR costs, as usually a higher number of social activities entails higher expenses (Du, Bhattacharya, and Sen 2010). Prior research has established that customers engage in such cost-related inferential reasoning when processing marketing campaigns (Kirmani and Wright 1989). High CSR costs may eventually lead customers to infer that the firm's social projects are sufficiently endowed with resources to effectively support the targeted social cause (Du, Bhattacharya, and Sen 2010). As a result, 
customers should be more likely to realize personal benefits from a firm's CSR engagementthat is, feel the warm glow of helping others (Andrews et al. 2014). Thus:

$\mathrm{H}_{3}$ : Firm CSR engagement has a positive indirect effect on customers' perceived CSR benefit via perceived level of firm CSR costs.

Beyond this positive indirect effect of level of firm CSR engagement on perceived CSR benefit, we expect the former to exhibit a positive indirect effect on perceived CSR price mark-up via perceived level of firm CSR costs. Prior price fairness research posits that customers possess basic knowledge of how firms operate and their financial requirements affecting customers' perceived price fairness (e.g., Kahneman, Knetsch, and Thaler 1986; Xia, Monroe, and Cox 2004). As Xia, Monroe, and Cox (2004, p. 6) state: “they [customers] develop knowledge of marketers' pricing tactics and of the relative cost-profit composition of a product's price. This metaknowledge, whether accurate or not, guides consumers' fairness judgments”. Thus, customers may expect firms to cover their costs to remain in business (Kalapurakal, Dickson, and Urbany 1991). Consequently, customers should be aware that a firm that carries high CSR costs must cover these expenses and may feel that "costs may be passed on through price" (Kirmani 1990, p. 163). We hypothesize:

$\mathrm{H}_{4}$ : Firm CSR engagement has a positive indirect effect on customers' perceived CSR price mark-up via perceived level of firm CSR costs.

Type of CSR engagement. Interacting with the level of firms' CSR engagement, we argue that the type of CSR engagement (i.e., philanthropic versus business-process CSR engagement) is a key characteristic shaping customers’ perceived level of firm CSR costs. Specifically, we predict that the positive effect of firm CSR engagement on perceived level of firm CSR cost is enhanced for philanthropic CSR engagement, since customers process philanthropic CSR engagement differently than business-process CSR engagement. Philanthropic CSR engagement comprises social activities targeted to stakeholders outside the firm such as people in need, non- 
governmental organizations, or local communities, and may take the form of monetary donations or support through providing equipment. Conversely, business-process CSR engagement focuses on intra-organizational stakeholders such as employees and may encompass employee support programs or the implementation of a more sustainable value chain (Homburg, Stierl, and Bornemann 2013).

We base our proposition for the interactive effect of level of firm CSR engagement and type of CSR engagement on two arguments: First, business process CSR engagement can imply significant financial payoffs for the firm, for example in the case of employee support programs which have been shown to significantly enhance the work engagement and productivity of the workforce (Bhattacharya, Sen, and Korschun 2008). Thus, the firm is a direct beneficiary of the CSR engagement itself. In case of philanthropic CSR engagement, potential benefits for the firm unfold more indirectly via enhanced attitudes of firm-external stakeholders. When inferring the level of a firm's CSR costs from the level of its CSR engagement, customers may factor in their perceptions of the higher direct benefits that firms derive from business-process CSR as compared to philanthropic CSR engagement. As a result, customers may infer lower costs from business-process CSR engagement than from philanthropic CSR engagement.

Second, philanthropic CSR engagement implies an instant benefit to society which can be measured in cash-value, whereas business process CSR engagement presents a societal benefit that is more indirect and may be perceived by customers as only paying off in the long run. Although business-process CSR engagement may be equally expensive for firms as philanthropic CSR engagement, instances of philanthropy and the dollar value related to this type of CSR engagement may thus be more salient to customers (Sen, Bhattacharya, and Korschun 2006). We therefore expect that the effect of firm CSR engagement on perceived level of firm costs is enhanced for philanthropic CSR engagement. Thus: 
$\mathrm{H}_{5}$ : The positive effect of firm CSR engagement on perceived level of firm CSR costs is more pronounced for philanthropic than for business process CSR engagement.

Intrinsic attributions and type of firm CSR cost. In Study 3 we seek to refine the results of Study 2 by providing a detailed explanation of the specific inferential mechanisms underlying the firm CSR engagement-perceived price fairness linkage. Therefore, $\mathrm{H}_{6}$ mirrors $\mathrm{H}_{2 \mathrm{a}}$ and $\mathrm{H}_{2 b}$ where we argue that both the positive and negative indirect effects of CSR engagement on perceived price fairness via customers’ perceived CSR benefit and CSR price mark-up are moderated by customers' CSR attribution. However, in $\mathrm{H}_{6}$ we focus on the moderating influence of the promotional CSR cost type perception, which is closely associated with customers’ CSR attribution. In particular, we expect that customers who perceive a firm's CSR engagement to be extrinsically motivated are more likely to perceive the firm's CSR costs as promotional. If customers perceive CSR costs are promotional, customers may be more likely to expect that a company marks up its prices to finance these costs and less likely to factor in perceived CSR benefit when evaluating price fairness. Consequently, we expect the same pattern of results to emerge for the moderating influence of promotional cost type perception as for intrinsic CSR attributions in Study 2. Therefore, we hypothesize:

$\mathrm{H}_{6}$ : The greater the extent to which customers perceive firms' CSR costs as promotional costs, the weaker the positive and the stronger the negative indirect effect of CSR engagement on perceived price fairness.

\section{Study 1: The Contingent Basic Effect of CSR on Price Fairness}

Study 1 investigates the effect of the level of firm CSR engagement on perceived price fairness in a representative cross-industry sample while taking into account customers’ perception of the company’s motivation for engaging in CSR (i.e., intrinsic CSR attribution). 


\section{Method}

Design of the study. We used a between-subjects scenario experiment and manipulated participants’ perceived level of firm CSR engagement. To this end, we recruited 2,248 respondents, asking them to evaluate one company from a set of 74 firms (30 respondents for each company). The 74 companies represented a cross-industry sample of major business-toconsumer brands as indicated by Interbrand ${ }^{1}$ (such as Apple, BMW, Gilette, and Walmart). Research assistants recruited respondents by asking pedestrians in the inner-city area to volunteer, randomly assigning them to either the experimental or the control group. Half of the participants (15 respondents per company) were given information about the firm’s most prominent CSR engagement to increase their perception of the company's level of CSR engagement. The other half did not receive this information, constituting the low perceived level of firm CSR engagement group.

In the first part of the questionnaire, we provided all respondents with a short description of the company (approximately 100 words) and asked them to what degree they were familiar with the company and had been customers of the company. Then, we provided the treatment group with a text that included information on the most prominent CSR engagement of the company (approximately 150 words). The control group received no information on the company’s CSR engagements. We took special care to make the text fragments as comparable as possible (Web Appendix W3 shows a sample text fragment for one company). All respondents were then asked to evaluate the price fairness of the company as well as their perception of the level of the company’s CSR engagement. Members of the treatment group were also asked to state whether they believed that intrinsic motives drove the company’s CSR engagement.

\footnotetext{
${ }^{1}$ http://www.interbrand.com/de/best-global-brands/2013/Best-Global-Brands-2013-Brand-View.aspx
} 
Sample description and measurement. The sample consisted of 2,248 respondents (48.9\% were male; the mean age was 29.9 years). Of the respondents, 1,180 reported they were familiar with the company and indicated they had patronized the company in the past. We chose only these respondents for the data analyses as they were able to make an informed judgment of the company’s prices. The Appendix shows our measures.

\section{Results}

Manipulation checks. We compared the mean values of participants' perception of the level of firm CSR engagement between the control and the experimental group (for measurement see Appendix). As the experimental group exhibits a significantly higher perceived level of firm CSR engagement $\left(\mathrm{M}_{\text {control group }}=3.38 ; \mathrm{M}_{\text {treatment group }}=3.81 ; \Delta \mathrm{M}=.43, \mathrm{t}=6.73, p<.000\right)$, we conclude that our treatments had the intended effect.

Hypotheses testing. We analyzed the effects of the experimental treatment with an ANOVA. Perceived price fairness varies significantly across the control and treatment group $(\mathrm{F}(1,1179)=4.77, p<.05)$. For the treatment group perceived price fairness is significantly lower than in the control group $\left(\mathrm{M}_{\text {treatment group }}=4.02 ; \mathrm{M}_{\text {control group }}=4.13, p<.05\right)$. To explore the effect of intrinsic CSR attribution and hence test $\mathrm{H}_{1}$, we partitioned the treatment according to whether respondents believed the company to be intrinsically motivated to engage in CSR or not. As a cutoff point, we chose the median of the variable, which with a value of 4 is identical with the midpoint of the scale. For high intrinsic CSR attribution, perceived price fairness is significantly higher than for low intrinsic CSR attribution $\left(\mathrm{M}_{\text {high intrinsic CSR attribution }}=4.47\right.$; $\mathrm{M}_{\mathrm{low}}$ intrinsic CSR attribution $=3.73, \mathrm{~F}(1,581)=43.92, p<.05)$ confirming $\mathrm{H}_{1}$.

\section{Discussion of Study 1}

Study 1 revealed that the effect of a firm’s level of CSR engagement on customers' price fairness judgments is highly context-sensitive. In cases where customers attribute companies’ CSR 
activities to intrinsic motives, CSR engagement improved perceived price fairness. Conversely, in cases where customers did not attribute companies’ CSR activities to intrinsic motives, CSR worsened perceived price fairness. Moreover, as we expected, customers’ perceptions of the fairness of the companies’ prices significantly translate to customer loyalty intentions $(\mathrm{r}=.51, p$ $<$.000). The subsequent second study of our paper aimed at getting a deeper understanding of the underlying psychological processes that influence customers’ price fairness judgments in terms of perceived CSR benefit and perceived CSR price mark-up.

\section{Study 2: Weighing of CSR Benefit and Price Mark-up as Inferential Mechanisms}

\section{Research Context and Data Collection Procedure}

We conducted this study in cooperation with a large international retail company. The company engages in a variety of CSR activities that are typical of companies of its size and industry. We collected data from 1,703 customers via an online survey. To preclude a selection bias, we compared respondents and the company’s overall customer base on a number of variables, including age, gender, region, and income. As we found no significant differences $(p>.10)$, indicating that respondents were representative of the company's customer base, we are confident that a selection bias is not a major concern in our study. Seeing that our conceptual framework links several customer perceptions, we carefully designed the data collection to preclude a common method bias: we separated the measurement of independent and dependent variables by collecting data via two surveys with a time lag of eight weeks and collected customers' objective

revenue from company records for the eight-week period following the second survey (Podsakoff et al. 2003).

\section{Measurement, Reliability, and Validity Diagnostics}

The survey measurements for firm CSR engagement, perceived CSR benefit, perceived CSR price mark-up, perceived price fairness, and intrinsic CSR attribution are detailed in the 
Appendix. We controlled for two potentially intervening variables. First, we included customers’ attitude toward CSR (e.g., Lichtenstein, Drumwright, and Braig 2004), measured in the second survey. Second, we controlled for customer loyalty (e.g., Homburg, Wieseke, and Hoyer 2009), measuring it in the first survey to mitigate reverse causality issues. Table 1 shows correlations and reliability diagnostics for all variables. All survey measures achieved adequate values for Cronbach’s alpha (Nunnally 1978) and average variances extracted (Fornell and Larcker 1981). Furthermore, all constructs were discriminant according to the Fornell-Larcker criterion (Fornell and Larcker 1981).

Insert Table 1 about here

\section{Results}

Main results. We estimated the path model depicted in Figure 1 via Mplus 7 (Muthén and Muthén 2010). For the estimation of the mediation model, we followed recommendations of Preacher and Hayes (2008) and estimated the indirect effects as well as the direct effect simultaneously. The model achieved an adequate fit (comparative fit index $=.98$, Tucker-Lewis index $=.95$, root mean square error of approximation $=.04$, standardized root mean square residual $=.01$ ). Table 2 shows the estimated path coefficients. In the following, we interpret the results of the model estimation in light of $\mathrm{H}_{2 \mathrm{a}}$ and $\mathrm{H}_{2 \mathrm{~b}}$.

Insert Table 2 about here

In $\mathrm{H}_{2 \mathrm{a}}$, we proposed that the indirect effect firm CSR engagement $\rightarrow$ perceived CSR benefit $\rightarrow$ perceived price fairness is more positive for higher levels of intrinsic CSR attribution since intrinsic CSR attribution positively moderates the effect of perceived CSR benefit on price fairness. Results show that the effect of perceived CSR benefit on perceived price fairness is significantly positive $(\beta=.08, p<.01)$ and moderated by intrinsic CSR attribution $(\beta=.08, p<$ .01). Consequently, the indirect effect of firm CSR engagement on perceived price fairness via 
perceived CSR benefit depends on intrinsic CSR attribution: It is significantly positive as long as intrinsic CSR attribution is higher than half a standard deviation below the mean value of the scale (see bottom of Table 2). Thus, in full support of $\mathrm{H}_{2 \mathrm{a}}$, intrinsic CSR attribution positively moderates the indirect effect of firm CSR engagement on perceived price fairness via perceived CSR benefit.

In $\mathrm{H}_{2 b}$, we proposed that the indirect effect firm CSR engagement $\rightarrow$ perceived CSR price mark-up $\rightarrow$ perceived price fairness becomes more negative for lower levels of intrinsic CSR attribution since intrinsic CSR attribution negatively moderates the effect of firm CSR engagement on perceived CSR price mark-up. Results show that the effect of firm CSR engagement on perceived CSR price mark-up is insignificant $(\beta=.04, p>.05)$, but negatively moderated by intrinsic CSR attribution $(\beta=-.11, p<.01)$. Consequently, the indirect effect of firm CSR engagement on perceived price fairness via perceived CSR price mark-up depends on intrinsic CSR attribution: It is significantly negative as long as intrinsic CSR attribution is lower than quarter a standard deviation below the mean value of the scale (see bottom of Table 2). Thus, intrinsic CSR attribution negatively moderates the indirect effect of firm CSR engagement on perceived price fairness via perceived CSR price mark-up, supporting $\mathrm{H}_{2 b}$.

Supplemental analyses. We conducted three supplemental analyses to extend and verify the robustness of our findings. First, we analyzed whether perceived CSR benefit and perceived CSR price mark-up exert a two-way interaction effect, or even three-way interaction effect with intrinsic CSR attribution, on perceived price fairness. However, we found no significant interaction effects. Second, we analyzed our conceptual model for alternative outcome variables beyond perceived price fairness, that is, customers' perceived price-value ratio, quality, price sacrifice, and willingness to pay more. Results are depicted in Table 3 and are largely consistent with our main model: (1) The pattern of indirect effects for perceived price-value ratio as an 
outcome variable is similar to the pattern for perceived price fairness. This finding is to be expected, seeing that perceived price-value ratio likewise constitutes a price evaluation in the price information processing model (Jacoby and Olson 1977) and is by definition driven by a customers' evaluation of benefits and prices, which according to the concept of distributive justice are also the drivers of perceived price fairness (Homans 1961). (2) The pattern of indirect effects for perceived quality and perceived price sacrifice as outcome variables is consistent to the pattern for perceived price fairness. In particular, perceived quality is only affected by firm CSR engagement via perceived CSR benefit whereas perceived price sacrifice is only affected via perceived CSR price mark-up. (3) The pattern of indirect effects for willingness to pay more as an outcome variable is similar to the pattern for perceived price fairness. This finding is to be expected, seeing that WTP-related constructs are likely outcomes of perceived price fairness (Campbell 1999; Herrmann, Xia, Monroe, and Huber 2007; Martin, Ponder, and Lueg 2009). The high consistency across outcome variables underlines the robustness of our results.

Insert Table 3 about here

Third, to verify our latter explanation that willingness to pay more represents an outcome of perceived price fairness, we estimated a model in which we included both these constructs with an additional path from perceived price fairness on willingness to pay more. Results are discussed in Web Appendix W4 and suggest that in fact, perceived price fairness serves as a mediator in the causal chain linking firm CSR engagement to willingness to pay more.

\section{Discussion of Study 2}

Our results provide further support for the notion that CSR engagement has mixed effects on perceived price fairness and offer a conceptual explanation for this effect. With regard to positive effects, customers may draw benefits from a company’s CSR engagement, resulting in more favorable price fairness evaluations. However, results show that this causal chain holds only if 
customers perceive a company’s CSR engagement to be intrinsically motivated. Conversely, customers may infer elevated prices from the level of company’s CSR engagement, resulting in less favorable price fairness evaluations. Again, we find that this causal chain is highly contingent as it holds only for low intrinsic CSR attributions. Lastly, worth noting is that price fairness is positively associated with the subsequent revenue of a customer (see Table 2).

While Study 2 provides first insight into the psychological mechanisms linking a firm’s CSR engagement to customers’ price fairness perceptions, the study leaves three questions open which we aim to address in Study 3. First, Study 2 focused on customers' impression of a firm’s overall price fairness. To verify the robustness of our results, Study 3 zooms in on one particular transaction between a firm and a customer. That is, in Study 3 we examine how customers' perception of a firm’s CSR engagement influences customers' inferences regarding CSR benefit, CSR price mark-up, and price fairness for a specific product. Second, owing to its survey design Study 2 was not fully able to establish causal relationships between the level of a firm's CSR engagement and customers' perceptions of CSR benefits, CSR price mark-ups, and price fairness. Hence, to provide stronger evidence for causality, Study 3 comprises an experiment in which we manipulated the independent variables and subsequently measured the dependent variables through survey scales. Third and most importantly, Study 2 did not address our predictions in $\mathrm{H}_{3}$ through $\mathrm{H}_{6}$ regarding the roles of the level of firms' CSR costs, the type of firms' CSR costs, and the type of CSR engagement (philanthropic versus business-process). Therefore, in Study 3 we experimentally manipulated level of firm CSR engagement, customers’ CSR attributions (intrinsinc vs. extrinsic), and type of CSR (philanthropic vs. business-process activities) to assess whether our results from Study 2 might be explained in terms of customers' firm CSR cost perceptions derived from a cost signaling perspective (Kirmani and Rao 2000). 


\section{Study 3 - Perceived Level and Type of Firm CSR Costs as Inferential Mechanisms}

\section{Method}

Stimuli and experimental design. We acquired 885 customers through a consumer panel (62\% female; mean age of 42.1 years) and randomly assigned them to eight conditions in a 2 (firm CSR engagement: low versus high) $\times 2$ (CSR attribution: intrinsic versus extrinsic) $\times 2$ (type of firm CSR engagement: philanthropic versus business process) between-subjects design. To render the scenarios highly realistic to the participants, we simulated the purchase of a brand-name external hard drive. In line with prior research, we manipulated customers' perceptions of the retailer’s CSR by providing information on the level and type of the retailer's CSR engagement and its motive for engaging in social activities (e.g., Barone et al. 2000; Andrews et al. 2014).

Procedure. We instructed customers to imagine that they intended to purchase an external hard drive from the electronics brand PowerMart and visited a store of the brand. We then provided information on the CSR engagement of PowerMart. In the high CSR engagement condition, participants were informed that PowerMart conducts social activities to a high extent, while in the low CSR engagement condition participants were told that PowerMart conducts social activities to only a low extent (Mohr and Webb 2005). The corresponding treatment dummy equips us with a rigorous measure of the level of firm CSR engagement, which allows us to conclude how an increase of firm CSR engagement from low to high causally influences our variables (Mohr and Webb 2005; Spencer, Zanna, and Fong 2005).

Furthermore, building on our proposition in $\mathrm{H}_{5}$ that the effect of firm CSR engagement on perceived level of firm CSR costs depends on whether the CSR engagement is philanthropic or related to business processes, we manipulated the type of the firm's CSR engagement. In the philanthropic CSR condition, we told participants that PowerMart donates money to people in need whereas in the business process CSR condition, we specified that PowerMart designs its 
supply chain and production processes in an environmentally friendly and sustainable manner (Homburg, Stierl, and Bornemann 2013).

Subsequently, we manipulated participants’ CSR attribution. In the intrinsic CSR motive condition, we informed participants that PowerMart engages in social activities owing to a genuine interest in societal welfare, whereas in the extrinsic CSR motive condition we depicted PowerMart as engaging in CSR activities on profit and image grounds (Du, Bhattacharya, and Sen 2007). Finally, we told participants to imagine that when shopping in the PowerMart store they found an external hard drive which suits their needs and we provided information on the hard drive, including its price. We then surveyed participants on their perceptions of this purchase scenario with regard to price and CSR perceptions.

Measures. The Appendix provides details for all scales. Drawing on a cost signaling perspective across $\mathrm{H}_{3}$ to $\mathrm{H}_{6}$ we argue that the mixed effects of firm CSR engagement on perceived fairness may be accounted for by customers’ inferences of firm CSR costs. Therefore, in Study 3 we newly introduce the constructs perceived level of firm CSR costs and perceived promotional CSR cost type adopting scales from Kirmani $(1990,1997)$ and adjusting them to the study’s context. Table 1 shows correlations and reliability diagnostics for all variables. All survey measures achieved adequate psychometric properties.

Control variables. To factor out the effects of other, potentially intervening variables, we included a number of controls derived from prior research. In particular, we controlled for customers’ price knowledge (Lichtenstein, Ridgway, and Netemeyer 1993) and perceived firm fairness image (Bolton, Keh, and Alba 2010).

\section{Results}

Analytical approach. We specified the structural equation path model as displayed in Figure 1.

The model comprises the hypothesized paths from firm CSR engagement to customers’ perceived 
price fairness via perceived level of firm CSR costs and customers’ perceived CSR benefit as well as perceived CSR price mark-up. Moreover, we included the moderating effect of the type of firm CSR engagement on the effect of firm CSR engagement on perceived level of firm CSR costs and the moderating effects of promotional CSR cost type perception. To incorporate the experimental treatments into the model, we coded three binary dummy variables (Bagozzi and Yi 1989). These dummy variables represent the three treatments: (1) firm CSR engagement (with high engagement coded as 1), (2) intrinsic (versus extrinsic) CSR attribution (with intrinsic motive coded as 1), and (3) type of firm CSR engagement (with philanthropic CSR engagement coded as 1). As a first step, we verified and found that all manipulations worked as intended. Details on the manipulation checks are presented in Web Appendix W5. We estimated the proposed models employing Mplus 7 (Muthén and Muthén 2010).

Hypotheses tests. The model fits the data well (comparative fit index $=.95$, Tucker-Lewis index $=.95$, root mean square error of approximation $=.03$, standardized root mean square residual $=.04)$. In sum, the model estimation corroborates our predictions (Table 4 depicts results of the model estimation). In $\mathrm{H}_{3}$ we predicted a positive indirect effect of firm CSR engagement on customers' perceived CSR benefits via perceived firm CSR level. For the estimation of the mediation models, we followed recommendations of Preacher and Hayes (2008) and estimated the indirect effects as well as the direct effect simultaneously. The indirect effect of firm CSR engagement on perceived CSR benefits is positive and significant, lending support to $\mathrm{H}_{3}\left(\beta_{\text {indirect }}\right.$ $=.12, p<.01)$. In $\mathrm{H}_{4}$ we predicted a positive indirect effect of firm CSR engagement on customers’ perceived CSR price mark-up via perceived firm CSR level. The indirect effect of firm CSR engagement on perceived CSR price mark-up is positive and significant, lending support to $\mathrm{H}_{4}\left(\beta_{\text {indirect }}=.09, p<.01\right)$. Furthermore, $\mathrm{H}_{5}$ suggested that the positive effect of firm CSR engagement on perceived level of firm CSR costs is more pronounced for philanthropic 
engagement than for business process CSR engagement (with philanthropic coded as 1), which is confirmed $(\beta=.17, p<.01)$. However, while $\mathrm{H}_{5}$ is supported, for low firm CSR engagement the mean level of perceived CSR costs is lower for philanthropic than for business-process CSR, which we discuss as an avenue for future research in the discussion.

Finally, in $\mathrm{H}_{6}$ we proposed that the more customers view firms' CSR costs as promotion costs, the stronger (weaker) the negative (positive) indirect effect of firm CSR engagement on perceived price fairness. To test this hypothesis, we calculated the respective indirect effects for low and high levels of promotional CSR cost type perception using the coefficients resulting from the model estimation (see Preacher and Hayes 2008). As expected, for high perception levels of promotional cost type, the negative indirect effect of firm CSR engagement on perceived price fairness is significant $\left(\beta_{\text {negative indirect }}=-.01, p<.05\right)$ whereas the positive indirect effect is insignificant ( $\beta_{\text {positive indirect }}=.01, p>$.05). Conversely, for low perception levels of promotional cost type, the positive indirect effect is significant $\left(\beta_{\text {positive indirect }}=.03, p<.01\right)$ whereas the negative indirect effect of firm CSR engagement on perceived price fairness is insignificant $\left(\beta_{\text {negative indirect }}=-.005, p>.05\right)$. This result confirms $\mathrm{H}_{6}$. Notably, the direct effect of firm CSR engagement on perceived price fairness is not significant $(\beta=.02, p>.05)$, indicating that the proposed inferential mechanisms fully mediate this relationship and providing additional support to our conceptual framework. Moreover, as we expected, perceived price fairness increases customers' loyalty intentions $(\beta=.40, p<.01)$.

Insert Table 4 about here

\section{Discussion of Study 3}

In Study 3 we explored the role of firms’ CSR cost level and cost type as inferred by the customer and hence clarify the psychological mechanisms underlying the firm CSR engagementperceived price fairness linkage. Results of Study 3 are fully consistent with findings in Study 2 
and underline that customers' inferences of firms’ CSR costs play a key role in understanding the mixed and contingent effects of firm CSR engagement on perceived price fairness as suggested by Kirmani’s and Rao’s (2000) cost signaling framework. Identifying firms’ CSR costs as a key mediator in our conceptual framework, we find that a firm’s CSR engagement increases customers' inference of the level of firms’ CSR costs, which in turn enhances both customers’ perceived CSR benefit and perceived CSR price mark-up $\left(\mathrm{H}_{3}\right.$ and $\left.\mathrm{H}_{4}\right)$.

Moreover, we isolate the type of firm CSR cost, that is, the extent to which CSR expenses are perceived as promotional, as the decisive inference underlying the moderating influence of intrinsic attributions on the firm CSR engagement-perceived price fairness linkage. We find that if customers perceive firm CSR costs as promotional, the negative indirect effect of firm CSR engagement on perceived price fairness prevails over the positive effect, with the positive exceeding the negative indirect effect if firm CSR expenses are not perceived as promotional costs $\left(\mathrm{H}_{6}\right)$. A limitation to be acknowledged is that in practice the causality between intrinsic CSR attribution and promotional CSR cost type perception may be bidirectional: While our experimental design supports the conclusion that extrinsic CSR attribution causally increases promotional CSR cost type perception, it may well be that framing CSR costs as investments into promotion also causally increases extrinsic attribution.

Lastly, regarding the influence of philanthropic vs. business-process CSR $\left(\mathrm{H}_{5}\right)$, we could confirm our prediction that the effect of firm CSR engagement on perceived level of firm CSR cost is enhanced for philanthropic CSR.

\section{Study 4: Remedy Strategies to Alleviate Negative Effects of CSR on Price Fairness}

In the previous studies we showed that customers who do not attribute a firm's CSR engagement to intrinsic motives evaluate the firm's prices as less fair. This finding has momentous implications for practice since customers frequently attribute CSR engagement to extrinsic 
motives and are reluctant to change this attribution (Skarmeas and Leonidu 2013). Therefore, a crucial question for managers is how to prevent negative effects of CSR engagement on customers’ perceived price fairness despite customers’ extrinsic attribution. To answer this question, in the following we conceptualize and test corresponding remedy strategies.

Development of a conceptual basis for these strategies depends on understanding what exactly these strategies should remedy. In Studies 2 and 3, we showed that the major reason for the decline of customers' perceived price fairness is that customers assume firms pass on their costs of extrinsically motivated CSR engagement through price mark-ups. Two viable remedies may thus be to (a) alleviate the positive association between CSR engagement and customers’ inferences of price mark-ups and (b) alleviate the negative association between perceived price mark-ups and perceived price fairness.

Building on diagnosticity theory (Feldman and Lynch 1988) and the dual entitlement principle (Kahnemann, Knetsch, and Thaler 1986), in the following we argue that managers can pursue both remedies (a) and (b) by communicating the sources of the budget for extrinsically motivated CSR engagement. More specifically, firms may finance their CSR engagement from two generic sources: They may reduce other costs (such as advertising costs or executive salaries) to fund CSR engagement or devote a portion of their given profit to CSR engagement. In the following, we explain in detail how communicating these sources of the CSR engagement budget may alleviate negative effects of extrinsically perceived CSR engagement on perceived price fairness. First, diagnosticity theory offers a suitable conceptual frame for convincing customers that CSR activities are financed through measures other than price mark-ups (i.e., remedy (a) mentioned previously). Diagnosticity theory posits that to make inferences individuals rely on the most useful cues available and refrain from using other, less useful cues (e.g., Feldman and Lynch 1988; Skowronski and Carlston 1987). Thus, when customers form a judgment of how a 
firm pays for its CSR engagement, they rely on cues that reveal the source of the CSR budget. If a useful cue suggests that CSR engagement is paid for by means other than price mark-ups, customers should be less likely to infer such mark-ups. Building on this idea, if firms communicate that they finance CSR engagement from the reduction of other costs or from the firm's profit, customers may be less likely to infer a price mark-up and perceive lower price fairness (e.g., Feldman and Lynch 1988).

Second, the dual entitlement principle proposes that even if customers infer price markups from CSR engagement, these price mark-ups do not necessarily impair perceived price fairness (i.e., remedy (b) mentioned previously). More specifically, the dual entitlement principle posits that in customers' view companies are entitled to a reference profit and customers are entitled to a reference price (Kahnemann, Knetsch, and Thaler 1986). As a result, customers are more likely to judge a price increase as fair if a firm faces rising costs or decreasing profits (e.g., Kahnemann, Knetsch, and Thaler 1986).

Based on the dual entitlement principle, we expect that communicating a firm's CSR engagement to be financed from the reduction of other costs or from the firm's profit alleviates the negative effect of perceived CSR price mark-up on perceived price fairness. To elaborate, if a firm communicates that its CSR engagement is financed from existing cost budgets, this information may raise customers' awareness for the costs associated with a firm's social activities. Similarly, if a firm communicates that its CSR engagement is financed from its profit, customers may acknowledge that CSR engagement negatively impacts a firm's bottom line. As a result of both communication strategies, customers may be more likely to grant a firm the right to mark up its prices, alleviating the negative effect of perceived CSR price mark-up on perceived price fairness (Kahnemann, Knetsch, and Thaler 1986). In essence, we argue:

$\mathrm{H}_{7}$ : Signaling the funding source for an extrinsically attributed CSR engagement 
increases customers' perceived price fairness as compared to not signaling the funding source of the CSR engagement budget.

\section{Method}

Stimuli and experimental design. To test $\mathrm{H}_{7}$, we devised a scenario experiment in which we simulated the purchase of a pair of jeans from a clothing store engaging in CSR activities. Our basic approach is to compare perceived price fairness for a firm's extrinsically perceived CSR engagement with a remedy strategy to extrinsically perceived CSR engagement without a remedy strategy and additional control conditions. The design comprised six experimental groups. We devised three experimental treatments communicating the budget source of extrinsically motivated CSR engagement: Advertising budget (i.e., the reduction of other costs), executive salaries (i.e., the reduction of other costs), and profit. To evaluate the effectiveness of these treatments, we devised three control groups: (1) extrinsically motivated CSR engagement without a remedy strategy — that is, without an indication of the budget source ("no remedy" condition); (2) extrinsically motivated CSR engagement including the information that the CSR engagement is not financed through a price mark-up (“no price mark-up” condition); and (3) intrinsically motivated CSR engagement (“intrinsic attribution” condition). We randomly assigned 245 customers acquired through an online consumer panel to these six conditions (67\% female; mean age of 42 years).

Procedure. We instructed participants to imagine that they intended to purchase a pair of jeans from the brand YourStyle and therefore visited a store of the brand. We then provided the information that YourStyle engaged in social responsibility activities. Subsequently, we manipulated customers' CSR attribution. In the intrinsic attribution condition, we communicated that YourStyle engaged in CSR out of a genuine interest in societal welfare, whereas in all other treatments, we communicated that YourStyle engaged in CSR to improve its profit and image 
(Barone et al. 2000). We then provided information on the source of the CSR budget. Finally, we told participants to imagine that during their store visit they found a pair of jeans that suited their needs, priced at €89.99.

Measures. We surveyed participants’ loyalty intentions and perceived price fairness of the pair of jeans using the same operationalization as in Study 3. Both scales achieved very good reliability $\left(\alpha_{\text {customer loyalty }}=.93, \alpha_{\text {perceived price fairness }}=.96\right)$.

\section{Results and Discussion}

Hypotheses tests. All manipulations worked as intended. Details on the manipulation checks are presented in Web Appendix W6. Using ANOVAs, we tested our hypotheses by analyzing differences in participants’ evaluation of perceived price fairness across the treatment and control conditions. Figure 2 shows the mean values and ANOVA results. Insert Figure 2 about here

$\mathrm{H}_{7}$ proposed that signaling the funding source for an extrinsically attributed CSR engagement increases customers’ perceived price fairness as compared to not signaling the funding source of the CSR engagement budget. This proposition holds for all treatment conditions: Participants evaluated perceived price fairness as significantly higher in each treatment condition than in the no remedy condition $(p<.05)$ and not different from the no price mark-up $(p>.50)$ and intrinsic attribution $(p>.40)$ conditions. Hence, $\mathrm{H}_{7}$ is supported. Lastly, the correlation between perceived price fairness and loyalty intentions is positive and highly significant $(r=.54, p<.001)$, showing that in line with our conceptual framework (see Figure 2), perceived price fairness is associated with customer loyalty.

In essence, Study 4 demonstrates that firms may take measures to alleviate the negative effects of extrinsically attributed CSR engagement on perceived price fairness. By communicating that the budget for their CSR engagement stems either from cost reductions (i.e., 
from their advertising budget or from a reduction of executive salaries) or from firm profit, firms are able to generate price fairness evaluations comparable to those for intrinsically attributed CSR engagement.

\section{General Discussion}

\section{Research Issues}

Prior research on the outcomes of CSR engagement has predominantly focused on customer benefits while neglecting to consider that firms' social activities might trigger price mark-up inferences. Consequently, prior marketing research cannot fully explain the firm CSR engagement-perceived price fairness relationship since customers evaluate price fairness on the basis of both perceived benefits and costs (Xia, Monroe, and Cox 2004).

Our study resolves the conceptual ambiguity relating to the firm CSR engagementperceived price fairness relationship by showing that firms' social activities have mixed effects on perceived price fairness. Firm CSR engagement increases perceived price fairness for high levels of customers' intrinsic CSR attribution via perceived CSR benefit, while it reduces perceived price fairness for low levels of intrinsic CSR attribution via a perceived CSR price mark-up. Drawing on work on costs signals in marketing (Kirmani and Rao 2000), we account for these findings in terms of customers' perceived level and type of firm CSR costs. Our findings have three key contributions for marketing research.

First, lending support to recent works that criticized the lack of understanding of psychological mechanisms underlying customers' responses to CSR engagement (Aguinis and Glavas 2012), our study indicates that prior CSR research has neglected the inherent complexity of customers' perception of companies' CSR engagement. Our results point to an important oversight pertaining to potential detrimental effects of CSR engagement. While customers benefit from a warm glow of helping others (e.g., Koschate-Fischer, Stefan, and Hoyer 2012), they are 
also aware of the high costs of CSR activities and critically deliberate potential price mark-ups resulting from these elevated costs. Thus, customer perceptions of CSR engagement can be thought of as two sides of a coin, with the benefit of a "warm glow" on one side and the "cold prickle" of costs on the reverse side.

Second, prior research holds conflicting views on the influence of firm costs on customer perceptions. For instance, while cost signaling approaches (Kirmani and Rao 2000) prescribe a momentous impact of firms' costs on customers’ perceptions and behavior (see also Kahneman, Knetsch, and Thaler 1986), other studies conclude that "consumers appear to have a poor appreciation of the costs faced by firms” (Bolton, Warlop, and Alba 2003, p. 475; see also Guo 2015). Our findings clearly support the former view by underlining the critical role of customers' cost perceptions in the CSR domain. The elevated apprehension of firms' CSR costs may result from an enhanced focus on firms' social activities owing to rising levels of customer skepticism of CSR (Skarmeas and Leonidu 2013). However, as heightened levels of customer skepticism and knowledge are not restricted to the CSR domain, we suggest that customers in general may focus more on firm costs. This development implies that cost signaling approaches (e.g., Kirmani and Rao 2000) should receive more attention in marketing research on consumer behavior. Our results illustrate that the perceived level and type of firm CSR costs as cost signals constitute viable explanations for the inferential mechanisms underlying the firm CSR engagementperceived price fairness relationship.

Furthermore, in line with our prediction in $\mathrm{H}_{5}$, we find that the effect of firm CSR engagement on perceived level of firm CSR cost is stronger for philanthropic as compared to business-process CSR. However, for low levels of firm CSR engagement customers seem to associate higher levels of firm CSR costs with business-process CSR engagement ( $\beta_{\text {philanthropic CSR }}$ engagement $\rightarrow$ perceived level of firm CSR $=-.10, p<.05$, see Table 4). This finding discloses interesting 
avenues for future research to explore customers' CSR cost perceptions for various CSR types. For instance, future work may verify whether customers make cost inferences of CSR types rather heuristically, i.e. on the basis of mental accessibility (Feldman and Lynch 1988), or rather systematically on the basis of mental calculations.

Third, a key finding of our study pertains to the negative effect of CSR engagement on perceived price fairness via perceived CSR price mark-up in the case of low intrinsic or rather extrinsic attributions. We devise and verify CSR communication strategies to remedy the potential negative effect of firms' social engagement on price fairness. Importantly, the remedy strategies are based on preventing customers from inferring CSR price mark-ups by guiding customers’ perceptions of firms' CSR costs.

A limitation of Study 4 is that we do not answer which actions firms can take to change customers' attributions from extrinsic to intrinsic, although knowledge of such actions would be highly desirable from a managerial perspective (e.g., Du, Bhattacharya, and Sen 2010; Vlachos et al. 2009; Yoon, Gürhan-Canli, and Schwarz 2006). Thus, examining ways to change customers' CSR attributions provides an interesting direction for future research, which could potentially leverage existing insights from attribution theory and the schemer schema.

\section{Managerial Implications}

Prior research has somewhat misled CSR managers in that numerous studies have established a variety of positive outcomes of CSR engagement, such as an improvement of corporate reputation, customer loyalty, and willingness to pay. However, our studies show that CSR is not a universal remedy to improve customer attitudes. We provide evidence that CSR engagement potentially reaches its limit as soon customers evaluate a company's price fairness. To optimally manage both CSR communication and a company's pricing, managers need to be aware of the underlying mechanisms. Our studies provide two core recommendations. 
First, managers need to understand that customers regard a company’s CSR investment as both beneficial and costly, causing mixed effects of CSR activities on price fairness. These results suggest that managers should frame the benefit/cost ratio of their CSR activities in a positive light by fostering customers’ benefit perceptions while toning down cost perceptions.

Second, managers need to generally bear in mind that customers' attributions of the company’s CSR motives play a crucial role in price fairness evaluations. CSR engagement only increases perceived price fairness if customers view the engagement as intrinsically motivated. Hence, managers should make sure that customers perceive a company's motives to engage in CSR actions in a positive light. This is a challenging task, as simply framing motives as intrinsic may actually arouse customers’ suspicion (Ellen, Webb, and Mohr 2006). Therefore, managers’ best shot may be to communicate CSR engagement in an authentic and honest way. They should also pretest CSR communication to examine how this communication affects inferences regarding motives in the market place. In this respect, our fourth study provides actionable advice for managers seeking effective communication strategies to publicize their CSR spending, preventing backlash effects in the case of extrinsic attribution. More specifically, explicit statements that a firm’s CSR spending is extracted from top management salaries, advertising budgets, or company profits constitute viable remedy strategies to counter potentially harmful effects on price fairness. 


\section{References}

Aguinis, Herman, and Ante Glavas (2012), “What We Know and Don’t Know About Corporate Social Responsibility: A Review and Research Agenda,” Journal of Management, 38 (4), 932-968.

Andrews, Michelle, Xueming Luo, Zheng Fang, and Jaakko Aspara (2014), "Cause Marketing Effectiveness and the Moderating Role of Price Discounts," Journal of Marketing, 78 (6), $120-142$.

Bagozzi, Richard P. and Youjae Yi (1989), "On the Use of Structural Equation Models in Experimental Designs,” Journal of Marketing Research, 26 (3), 271-284.

Barone, Michael J., Anthony D. Miyazaki, and Kimberly A. Taylor (2000), "The Influence of Cause-Related Marketing on Consumer Choice: Does one Good Turn Deserve Another?” Journal of the Academy of Marketing Science, 28 (2), 248-262.

Becker-Olsen, Karen L., B. Andrew Cudmore, and Ronald Paul Hill (2006), “The Impact of Perceived Corporate Social Responsibility on Consumer Behavior,” Journal of Business Research, 59 (1), 46-53.

Bhattacharya, C.B., Sankar Sen, and Daniel Korschun (2008), "Using Corporate Social Responsibility to Win the War for Talent,” MIT Sloan Management Review, 49 (2), 3744.

Blau, Peter M. (1964), Exchange and Power in Social Life. New York: Wiley.

- - - Hean Tat Keh, and Joseph W. Alba (2010), "How Do Price Fairness Perceptions Differ Across Culture?” Journal of Marketing Research, 47 (3), 564-576.

Bornemann, Torsten and Christian Homburg (2011), "Psychological Distance and the Dual Role of Price,” Journal of Consumer Research, 38 (3), 490-504.

Campbell, Margaret C. (1999), "Perceptions of Price Unfairness: Antecedents and Consequences,“ Journal of Marketing Research, 36 (2), 187-199.

- - (2007), "'Says who?!' How the Source of Price Information and Affect Influence Perceived Price (Un)fairness,“ Journal of Marketing Research, 44 (2), 261-271.

Chandler, David and William B. Werther (2014), Strategic Corporate Social Responsibility: Stakeholders, Globalization, and Sustainable Value Creation. Thousand Oaks: Sage Publications.

CorporateWatch (2006), "What's wrong with corporate social responsibility," https://corporatewatch.org/sites/default/files/CSRreport.pdf, Access: 23.09.2015. 
De Pelsmacker, Patrick, Liesbeth Driesen, and Glenn Rayp (2005), "Do Consumers Care about Ethics? Willingness to Pay for Fair-Trade Coffee,“ Journal of Consumer Affairs, 39 (2), 363-385.

Dodds, William B., Kent B. Monroe, and Dhruv Grewal (1991), "Effects of Price, Brand, and Store Information on Buyers' Product Evaluations," Journal of Marketing Research, 28 (3), 307-319.

Du, Shuili, Chitrabhan B. Bhattacharya, and Sankar Sen (2007), "Reaping Relational Rewards from Corporate Social Responsibility: The Role of Competitive Positioning," International Journal of Research in Marketing, 24 (3), 224-241.

- - - - - - and - - (2010), "Maximizing Business Returns to Corporate Social Responsibility (CSR): The Role of CSR Communication," International Journal of Management Reviews, 12 (1), 8-19.

Ellen, Pam S., Deborah J. Webb, and Lois A. Mohr (2006), "Building Corporate Associations: Consumer Attributions for Corporate Socially Responsible Programs," Journal of the Academy of Marketing Science, 34 (2), 147-157.

Erdem, Tülin and Joffre Swait (1998), "Brand Equity as a Signaling Phenomenon,” Journal of Consumer Psychology, 7 (2), 131-157.

Feldman, Jack M. and John G. Lynch (1988), "Self-Generated Validity and Other Effects of Measurement on Belief, Attitude, Intention, and Behavior," Journal of Applied Psychology, 73 (3), 421-435.

Forehand, Mark R. and Sonya Grier (2003), "When Is Honesty the Best Policy? The Effect of Stated Company Intent on Consumer Skepticism,” Journal of Consumer Psychology, 13 (3), 349-356.

Fornell, Claes and David F. Larcker (1981), "Evaluating Structural Equation Models with Unobservable Variables and Measurement Error,” Journal of Marketing Research, 18 (1), 39-50.

Gouldner, Alvin W. (1960), "The Norm of Reciprocity: A Preliminary Statement,” American Sociological Review, 161-178.

Guo, Liang (2015), “Inequity Aversion and Fair Selling,” Journal of Marketing Research, 52 (1), 77-89.

Herrmann, Andreas, Lan Xia, Kent B. Monroe, and Frank Huber (2007), “The Influence of Price Fairness on Customer Satisfaction: An Empirical Test in the Context of Automobile Purchases, “ Journal of Product \& Brand Management, 16 (1), 49-58.

Homans, George C. (1961), Social Behavior: Its Elementary Forms, New York: Harcourt Brace Jovanovich. 
Homburg, Christian, Marcel Stierl, and Torsten Bornemann (2013), "Corporate Social Responsibility in Business-to-Business Markets: How Organizational Customers Account for Supplier Corporate Social Responsibility Engagement,” Journal of Marketing, 77 (6), $54-72$.

- - - Jan Wieseke, and Wayne D. Hoyer (2009), "Social Identity and the Service-Profit Chain,” Journal of Marketing, 73 (2), 38-54.

Ippolito, Pauline M. (1990), "Bonding and Nonbonding Signals of Product Quality,” Journal of Business, 63 (1), 41-60.

Jacoby, Jacob and Olson, Jerry C. (1977), "Consumer Response to Price: An Attitudinal, Information Processing Perspective," in Moving Ahead With Attitude Research, Yoram Wind and Marshall Greenberg, eds. Chicago, 73-86.

Kahneman, Daniel, Jack L. Knetsch, and Richard Thaler (1986), "Fairness as a Constraint on Profit Seeking: Entitlements in the Market,” The American Economic Review, 76 (4), 728-741.

Kalapurakal, Rosemary, Peter R. Dickson, and Joel E. Urbany (1991), "Perceived Price Fairness and Dual Entitlement,” Advances in Consumer Research, 18 (1), 788-793.

Kelley, Harold H. (1967), “Attribution Theory in Social Psychology,” in Nebraska Symposium on Motivation, Vol. 15, David Levine, ed. Lincoln: University of Nebraska Press, 192-238.

Kirmani, Amna (1990), "The Effect of Perceived Advertising Costs on Brand Perceptions," Journal of Consumer Research, 17 (2), 160-171.

- - (1997), “Advertising Repetition as a Signal of Quality: If It’s Advertised so Much, Something Must Be Wrong,” Journal of Advertising, 26 (3), 77-86.

- - - and Akshay R. Rao (2000), "No Pain, No Gain: A Critical Review of the Literature on Signaling Unobservable Product Quality,” Journal of Marketing, 64 (2), 66-79.

- - , and Peter Wright (1989), "Money Talks: Perceived Advertising Expense and Expected Product Quality,” Journal of Consumer Research, 16 (3), 344-353.

Koschate-Fischer, Nicole, Isabel V. Stefan, and Wayne D. Hoyer (2012), "Willingness to Pay for Cause-Related Marketing: The Impact of Donation Amount and Moderating Effects," Journal of Marketing Research, 49 (6), 910-927.

Lichtenstein, Donald R., Minette E. Drumwright, and Bridgette M. Braig (2004), "The Effect of Corporate Social Responsibility on Customer Donations to Corporate-Supported Nonprofits,” Journal of Marketing, 68 (4), 16-32.

- - -, Nancy M. Ridgway, and Richard G. Netemeyer (1993), "Price Perceptions and Consumer Shopping Behavior: A Field Study,” Journal of Marketing Research, 30 (2), 234-245. 
Luo, Xueming and C. B. Bhattacharya (2006), “Corporate Social Responsibility, Customer Satisfaction, and Market Value,” Journal of Marketing, 70 (4), 1-18.

Martin, William C., Nicole Ponder, and Jason E. Lueg (2009), "Price Fairness Perceptions and Customer Loyalty in a Retail Context,” Journal of Business Research, 62 (6), 588-593.

Maxwell, Sarah (2002), "Rule-based price fairness and its effect on willingness to purchase," Journal of Economic Psychology, 23 (2), 191-211.

McWilliams, Abagail and Donald Siegel (2001), "Corporate Social Responsibility: A Theory of the Firm Perspective,” Academy of Management Review, 26 (1), 117-127.

Mohr, Lois A. and Deborah J. Webb (2005), “The Effects of Corporate Social Responsibility and Price on Consumer Responses,” Journal of Consumer Affairs, 39 (1), 121-147.

Muthén, Linda K. and Bengt O. Muthén (2010), Mplus User’s Guide, 6th ed. Los Angeles: Muthén \& Muthén.

Niedrich, Ronald W., Subhash Sharma, and Douglas H. Wedell (2001), "Reference Price and Price Perceptions: A Comparison of Alternative Models,” Journal of Consumer Research, 28 (3), 339-354.

Nunally, Jum C. (1978), Psychometric Theory. New York: McGraw-Hill.

Oliver, Richard L. and John E. Swan (1989), “Consumer Perceptions of Interpersonal Equity and Satisfaction in Transactions: a Field Survey Approach,” Journal of Marketing, 53 (2), 2135.

Podsakoff, Philip M., Scott B. MacKenzie, Lee Jeong-Yeon, and Nathan P. Podsakoff (2003), "Common Method Biases in Behavioral Research: A Critical Review of the Literature and Recommended Remedies,” Journal of Applied Psychology, 88 (5), 879-903.

Preacher, Kristofer J. and Andrew F. Hayes (2008), “Asymptotic and Resampling Strategies for Assessing and Comparing Indirect Effects in Multiple Mediator Models,” Behavior Research Methods, 40 (3), 879-891.

Sen, Sankar and Chitrabhan B. Bhattacharya (2001), "Does Doing Good Always Lead to Doing Better? Consumer Reactions to Corporate Social Responsibility,” Journal of Marketing Research, 38 (2), 225-243.

- - - , - - , and Daniel Korschun (2006), "The Role of Corporate Social Responsibility in Strengthening Multiple Stakeholder Relationships: A Field Experiment,” Journal of the Academy of Marketing Science, 34 (2), 158-166.

Skarmeas, Dionysis and Constantinos N. Leonidou (2013), "When Consumers Doubt, Watch out! The Role of CSR Skepticism,” Journal of Business Research, 66(10), 1831-1838. 
Skowronski, John J. and Donal E. Carlston (1987), “Social Judgement and Social Memory: The Role of Cue Diagnosticity in Negativity, Positivity, and Extremity Biases,” Journal of Personality and Social Psychology, 52 (4), 689-699.

Spencer, Steven J., Mark P. Zanna, and Geoffrey T. Fong (2005), "Establishing a Causal Chain: Why Experiments Are Often More Effective,” Journal of Personality and Social Psychology, 89 (6), 845-851.

Sweeney, Jillian C. and Geoffrey N. Soutar (2001), "Consumer Perceived Value: The Development of a Multiple Item Scale,” Journal of Retailing, 77 (2), 203-220.

Thaler, Richard (1985), "Mental Accounting and Consumer Choice,” Marketing Science, 4 (3), 199-215.

Thibaut, John W. and Harold H. Kelley (1959), The Social Psychology of Groups. Oxford: John Wiley.

Uleman, James S., S. Adil Saribay, and Celia M. Gonzalez (2008), "Spontaneous Inferences, Implicit Impressions, and Implicit Theories,” Annual Review of Psychology, 59, 329-360.

Unruh, Gregory (2011), “No, Consumers Will Not Pay More for Green,” Forbes, 28.07.2011.

Vlachos, Pavlos A., Argiris Tsamakos, Adam Vrechopoulos, and Panagiotis Avramidis (2009), "Corporate Social Responsibility: Attributions, Loyalty, and the Mediating Role of Trust,” Journal of the Academy of Marketing Science, 37 (2), 170-180.

Webb, Deborah J. and Lois A. Mohr (1998), “A Typology of Consumer Responses to CauseRelated Marketing: From Skeptics to Socially Concerned,” Journal of Public Policy \& Marketing, 17 (2), 226-238.

Wertenbroch, Klaus and Bernd Skiera (2002), "Measuring Consumers' Willingness to Pay at the Point of Purchase,” Journal of Marketing Research, 39 (2), 228-241.

Xia, Lan, Kent B. Monroe and Jennifer L. Cox (2004), “The Price Is Unfair! A Conceptual Framework of Price Fairness Perceptions,” Journal of Marketing, 68 (4), 1-15.

Yoon, Yeosun, Zeynep Gürhan-Canli, and Norbert Schwarz (2006), "The Effect of Corporate Social Responsibility (CSR) Activities on Companies with Bad Reputation,” Journal of Consumer Psychology, 16 (4), 377-390.

Zeithaml, Valarie A. (1984), "Issues in Conceptualizing and Measuring Consumer Response to Price,” Advances in Consumer Research, 11 (1), 612-616.

- - (1988), "Consumer Perceptions of Price, Quality, and Value: A Means-End Model and Synthesis of Evidence,” Journal of Marketing, 52 (3), 2-22.

- - Leonard L. Berry, and Ananthanarayanan Parasuraman (1996), "The Behavioral Consequences of Service Quality,” Journal of Marketing, 60 (2), 31-46. 
FIGURE 1. Overview of the Conceptual Framework

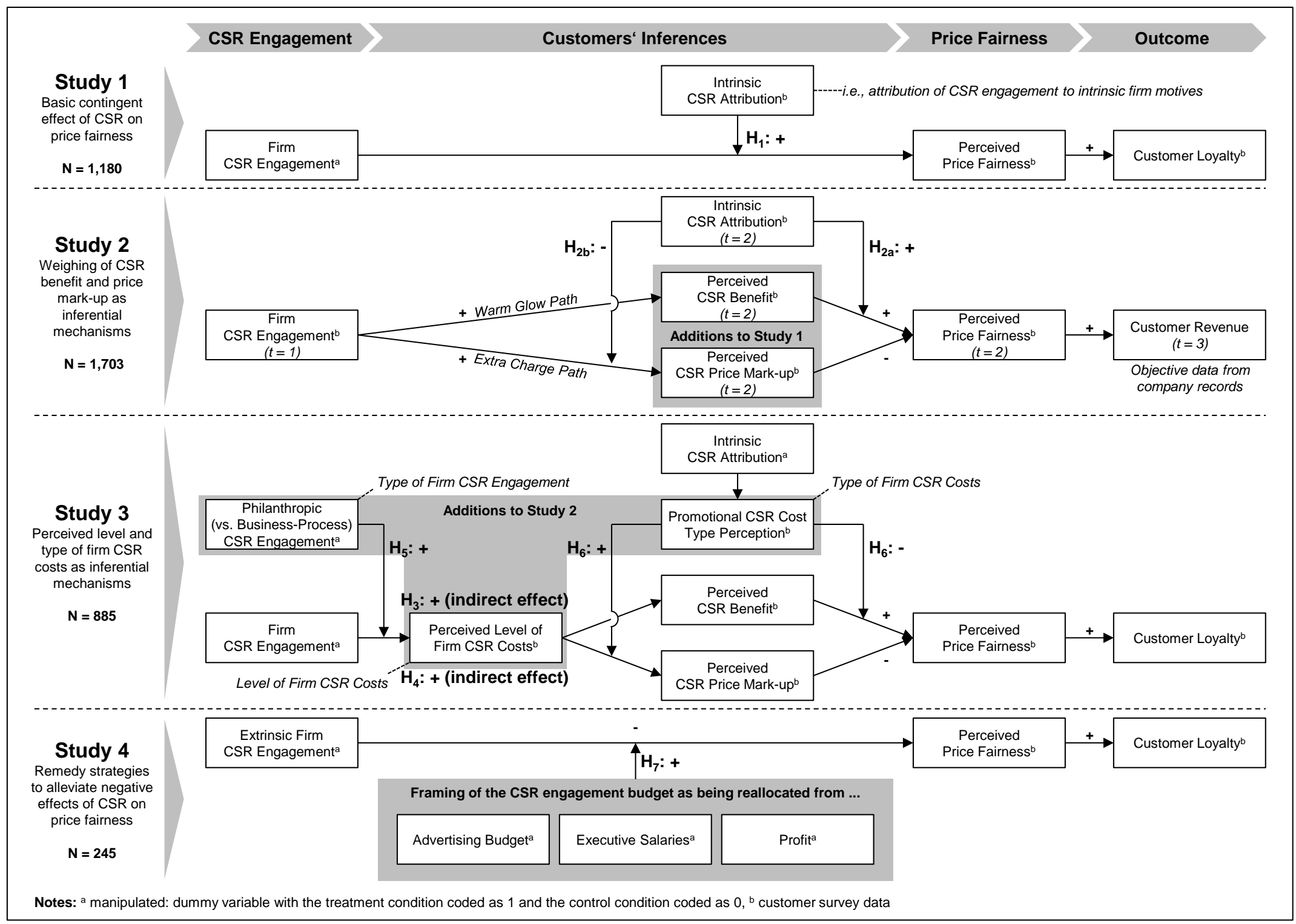


FIGURE 2. Results of Study 4

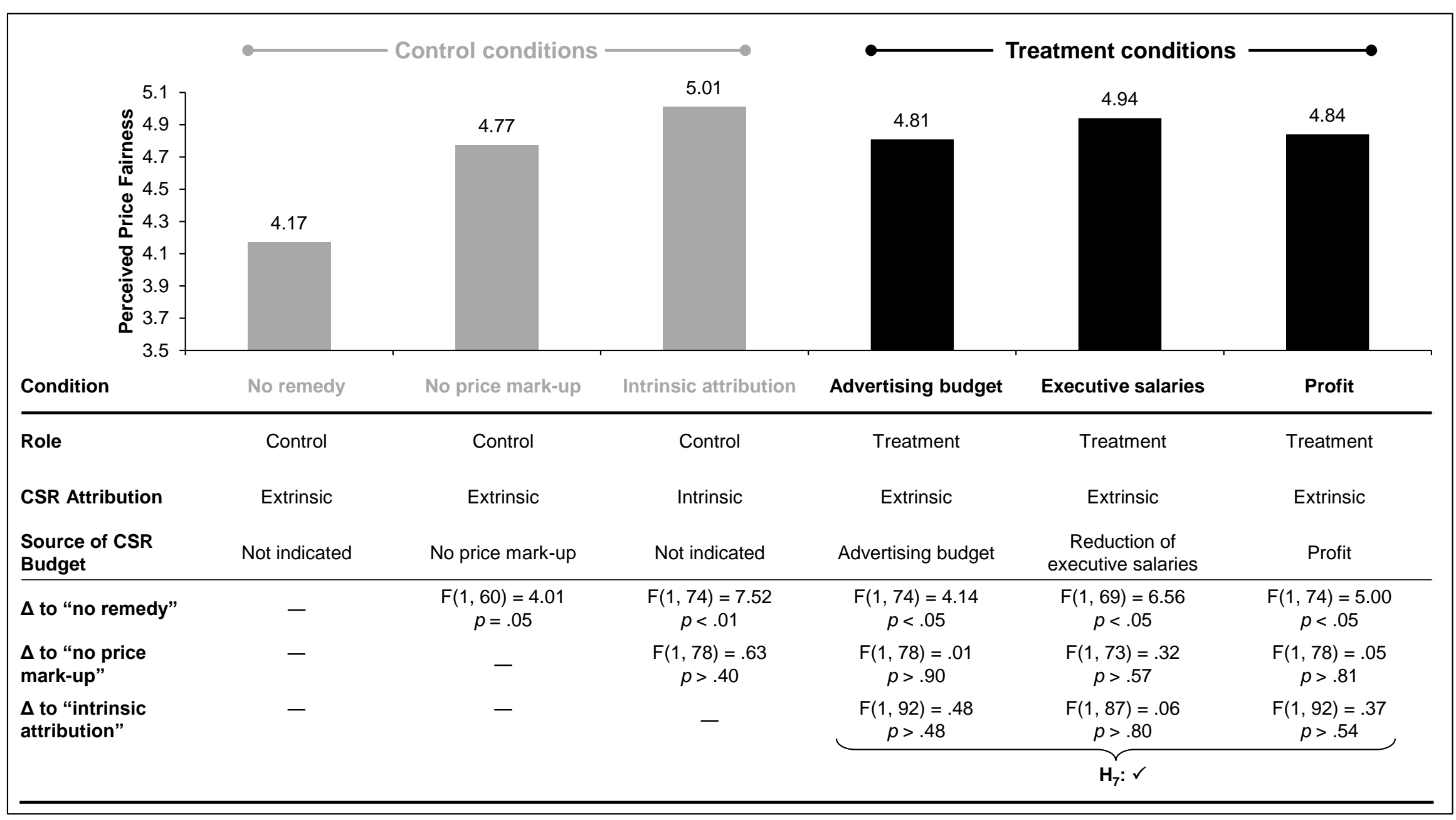




\section{TABLE 1}

Study 2 and Study 3: Descriptive Statistics and Correlations

\begin{tabular}{|c|c|c|c|c|c|c|c|c|c|c|c|c|}
\hline \multicolumn{13}{|c|}{ Study 2} \\
\hline Variable & $M$ & SD & $\alpha$ & AVE & 1 & 2 & 3 & 4 & & & & \\
\hline 1. Firm CSR engagement & 5.28 & 1.30 & .98 & .80 & & & & & & & & \\
\hline 2. Perceived CSR benefit & 4.07 & 1.41 & .88 & .75 & $.49 * *$ & & & & & & & \\
\hline 3. Perceived CSR price mark-up & 3.63 & 1.26 & .80 & .55 & $.05^{*}$ & $.11^{\star *}$ & & & & & & \\
\hline 4. Perceived price fairness & 5.26 & 1.06 & .90 & .78 & $.31^{\star \star}$ & $.30 * *$ & $-.10 * \star$ & & & & & \\
\hline 5. Intrinsic CSR attribution ${ }^{a}$ & 4.29 & 1.41 & $-^{a}$ & $-^{a}$ & $.57^{\star \star}$ & $.62^{\star \star}$ & .03 & $.35^{\star \star}$ & & & & \\
\hline \multicolumn{13}{|c|}{ Study 3} \\
\hline Variable & $M$ & SD & $\alpha$ & AVE & 1 & 2 & 3 & 4 & 5 & 6 & 7 & 8 \\
\hline 1. Firm CSR engagement ${ }^{\mathrm{b}}$ & $-{ }^{a}$ & $-^{a}$ & $-{ }^{a}$ & $-^{a}$ & & & & & & & & \\
\hline 2. Intrinsic CSR attribution ${ }^{\mathrm{b}}$ & $-^{a}$ & $-^{a}$ & $-^{a}$ & $-^{a}$ & .00 & & & & & & & \\
\hline 3. Philanthropic CSR engagement ${ }^{\mathrm{b}}$ & $-^{\mathrm{a}}$ & $-^{a}$ & $-^{a}$ & $-^{a}$ & .00 & .00 & & & & & & \\
\hline 4. Perceived level of firm CSR costs & 3.45 & 1.13 & .98 & .91 & $.40^{\star \star}$ & .05 & .01 & & & & & \\
\hline 5. Perceived CSR price mark-up & 4.77 & 1.17 & .81 & .62 & $.22^{\star \star}$ & -.02 & .04 & $.35^{\star \star}$ & & & & \\
\hline 6. Perceived CSR benefit & 3.86 & 1.36 & .93 & .81 & $.17^{\star \star}$ & $.13^{\star *}$ & .01 & $.42^{\star \star}$ & $.22^{\star \star}$ & & & \\
\hline 7. Perceived price fairness & 3.69 & 1.34 & .97 & .93 & $.14^{\star \star}$ & $.17^{\star \star}$ & -.02 & $.27^{\star \star}$ & .05 & $.41^{\star \star}$ & & \\
\hline 8. Promotional CSR cost type perception & 5.45 & 1.08 & .96 & .88 & .00 & $-.09^{\star \star}$ & .05 & -.02 & $.14^{\star \star}$ & $-.12^{\star \star}$ & $-.13^{\star \star}$ & \\
\hline 9. Customer loyalty & 2.91 & 1.45 & .95 & .87 & $.18^{\star \star}$ & $.13^{\star *}$ & -.02 & $.35^{\star \star}$ & $.07^{*}$ & $.61^{\star \star}$ & $.59 * *$ & $-.11^{\star *}$ \\
\hline
\end{tabular}

* $p<.05 ;{ }^{* \star} p<.01$ (two-tailed)

Note: $\mathrm{M}=$ Mean, $\mathrm{SD}=$ standard deviation, $\alpha=$ Cronbach's alpha, AVE = average variance extracted, ${ }^{\mathrm{a}}$ Single item measure, ${ }^{\mathrm{b}}$ dummy variable 
TABLE 2

\section{Study 2: Estimated Path Coefficients}

\begin{tabular}{|c|c|c|c|c|c|c|c|c|c|}
\hline \multicolumn{6}{|l|}{ Path } & \multirow[t]{2}{*}{ Hypothesis } & \multicolumn{3}{|c|}{ Estimated Coefficient } \\
\hline \multicolumn{9}{|l|}{ Warm Glow Path } & \\
\hline Firm CSR engagement & \multicolumn{5}{|c|}{$\rightarrow$ perceived CSR benefit } & & \multicolumn{3}{|c|}{$.17^{\star \star}$} \\
\hline Perceived CSR benefit & \multicolumn{5}{|c|}{$\rightarrow$ perceived price fairness } & & \multicolumn{3}{|c|}{$.08^{\star \star}$} \\
\hline \multicolumn{10}{|l|}{ Extra Charge Path } \\
\hline Firm CSR engagement & \multicolumn{6}{|c|}{$\rightarrow$ perceived CSR price mark-up } & \multicolumn{3}{|c|}{$.04^{\text {n.s. }}$} \\
\hline Perceived CSR price mark-up & \multicolumn{5}{|c|}{$\rightarrow$ perceived price fairness } & & \multicolumn{3}{|c|}{$-.09^{* *}$} \\
\hline \multicolumn{10}{|l|}{ Outcome } \\
\hline Price fairness & \multicolumn{5}{|c|}{$\rightarrow$ customer revenue } & & \multicolumn{3}{|c|}{$.06^{*}$} \\
\hline \multicolumn{10}{|l|}{ Interaction Effects } \\
\hline \multirow{2}{*}{\multicolumn{2}{|c|}{$\begin{array}{l}\text { Perceived CSR benefit } \times \text { intrinsic CSR attribution } \\
\text { Firm CSR engagement } \times \text { intrinsic CSR attribution }\end{array}$}} & \multicolumn{4}{|c|}{$\rightarrow$ perceived price fairness } & $\mathrm{H}_{2 \mathrm{a}}:+$ & \multicolumn{3}{|c|}{$.08^{\star \star}$} \\
\hline & & \multicolumn{4}{|c|}{$\rightarrow$ perceived CSR price mark-up } & $\mathrm{H}_{2 \mathrm{~b}}:-$ & \multicolumn{3}{|c|}{$-.11^{\star \star}$} \\
\hline \multicolumn{10}{|l|}{ Main Effects of Moderator } \\
\hline Intrinsic CSR attribution & \multicolumn{5}{|c|}{$\rightarrow$ perceived price fairness } & & \multicolumn{3}{|c|}{$.19 * \star$} \\
\hline Intrinsic CSR attribution & \multicolumn{5}{|c|}{$\rightarrow$ perceived CSR price mark-up } & & \multicolumn{3}{|c|}{$.02^{\text {n.s. }}$} \\
\hline \multicolumn{10}{|l|}{ Controlled Effects } \\
\hline Firm CSR engagement & & $\rightarrow$ pe & ceived pric & fairness & & & & $.03^{\text {n.s. }}$ & \\
\hline Firm CSR engagement & & $\rightarrow \mathrm{cu}$ & tomer reve & lue & & & & $-.00^{\text {n.s. }}$ & \\
\hline Intrinsic CSR attribution & & $\rightarrow$ pe & ceived CSF & benefit & & & & $.48^{\star \star}$ & \\
\hline Attitude toward CSR & & $\rightarrow$ pe & ceived CSF & benefit & & & & $.07^{\star \star}$ & \\
\hline Attitude toward CSR & & $\rightarrow$ pe & ceived CSF & price mark & & & & $.02^{\text {n.s. }}$ & \\
\hline Attitude toward CSR & & $\rightarrow$ pe & ceived pric & fairness & & & & $.08^{\star \star}$ & \\
\hline Customer loyalty & & $\rightarrow$ pe & ceived CSF & benefit & & & & $.07^{\star \star}$ & \\
\hline Customer loyalty & & $\rightarrow$ pe & ceived CSF & price mark & & & & $-.11^{\star \star}$ & \\
\hline Customer loyalty & & $\rightarrow$ pe & ceived pric & fairness & & & & $.26^{\star \star}$ & \\
\hline Customer loyalty & & $\rightarrow \mathrm{cu}$ & tomer reve & & & & & $-.02^{\text {n.s. }}$ & \\
\hline & & & & evel of Int & insic CSR & Attribution & & & \\
\hline Simple Slopes & $-1 * S D$ & $75 * S D$ & $-.5 * \mathrm{SD}$ & $-.25 * \mathrm{SD}$ & Mean & $+.25 * \mathrm{SD}$ & $+.5 * \mathrm{SD}$ & $+.75 * \mathrm{SD}$ & $+1 * S D$ \\
\hline $\begin{array}{l}\text { Perceived CSR benefit } \\
\rightarrow \text { perceived price fairness }\end{array}$ & $\begin{array}{c}.02 \\
(p=.52)\end{array}$ & $\begin{array}{l}.04 \\
=.24)\end{array}$ & $\begin{array}{c}.04 \\
(p=.08)\end{array}$ & $\begin{array}{c}.07 \\
(p=.02)\end{array}$ & $\begin{array}{c}.08 \\
(p=.00)\end{array}$ & $\begin{array}{c}.10 \\
(p=.00)\end{array}$ & $\begin{array}{c}.11 \\
(p=.00)\end{array}$ & $\begin{array}{c}.13 \\
(p=.00)\end{array}$ & $\begin{array}{c}.14 \\
(p=.00)\end{array}$ \\
\hline $\begin{array}{l}\text { Firm CSR engagement } \\
\rightarrow \text { perceived CSR price mark-up }\end{array}$ & $\begin{array}{c}.12 \\
(p=.00)\end{array}$ & $\begin{array}{l}.10 \\
=.00)\end{array}$ & $\begin{array}{c}.08 \\
(p=.01)\end{array}$ & $\begin{array}{c}.06 \\
(p=.05)\end{array}$ & $\begin{array}{c}.04 \\
(p=.21)\end{array}$ & $\begin{array}{c}.02 \\
(p=.53)\end{array}$ & $\begin{array}{c}.00 \\
(p=.95)\end{array}$ & $\begin{array}{c}-.02 \\
(p=.66)\end{array}$ & $\begin{array}{c}-.04 \\
(p=.39)\end{array}$ \\
\hline $\begin{array}{l}\text { Indirect Effects } \\
\text { (tested simultaneously) }\end{array}$ & & & & & & & & & \\
\hline $\begin{array}{l}\text { Firm CSR engagement } \\
\rightarrow \text { perceived CSR benefit } \\
\rightarrow \text { perceived price fairness }\left(\mathrm{H}_{2 \mathrm{a}}\right)\end{array}$ & $\begin{array}{c}.00 \\
(p=.52)\end{array}$ & $\begin{array}{l}.01 \\
=.24)\end{array}$ & $\begin{array}{c}.01 \\
(p=.09)\end{array}$ & $\begin{array}{c}.01 \\
(p=.03)\end{array}$ & $\begin{array}{c}.01 \\
(p=.01)\end{array}$ & $\begin{array}{c}.02 \\
(p=.00)\end{array}$ & $\begin{array}{c}.02 \\
(p=.00)\end{array}$ & $\begin{array}{c}.02 \\
(p=.00)\end{array}$ & $\begin{array}{c}.02 \\
(p=.00)\end{array}$ \\
\hline $\begin{array}{l}\text { Firm CSR engagement } \\
\rightarrow \text { perceived CSR price mark-up } \\
\rightarrow \text { perceived price fairness }\left(\mathrm{H}_{2 b}\right)\end{array}$ & $\begin{array}{c}-.01 \\
(p=.01)\end{array}$ & $\begin{array}{l}-.01 \\
=.01)\end{array}$ & $\begin{array}{c}-.01 \\
(p=.03)\end{array}$ & $\begin{array}{c}-.01 \\
(p=.08)\end{array}$ & $\begin{array}{c}-.00 \\
(p=.23)\end{array}$ & $\begin{array}{c}-.00 \\
(p=.54)\end{array}$ & $\begin{array}{c}.00 \\
(p=.95)\end{array}$ & $\begin{array}{c}.00 \\
(p=.67)\end{array}$ & $\begin{array}{c}.00^{\mathrm{n} . \mathrm{s}} \\
(p=.41)\end{array}$ \\
\hline
\end{tabular}

n.s. not significant, $p>.05,{ }^{\star} p<.05,{ }^{\star \star} p<.01$ (two-tailed); we report standardized coefficients; SD = standard deviation. 


\section{TABLE 3}

\section{Study 2: Estimated Path Coefficients for Alternative Outcomes}

\begin{tabular}{|c|c|c|c|c|c|c|}
\hline \multirow[b]{2}{*}{ Path } & & \multicolumn{5}{|c|}{ Dependent variable } \\
\hline & & $\begin{array}{c}\text { Perceived } \\
\text { price fairness }\end{array}$ & $\begin{array}{c}\text { Perceived } \\
\text { price-value ratio }\end{array}$ & $\begin{array}{l}\text { Perceived } \\
\text { quality }\end{array}$ & $\begin{array}{c}\text { Perceived } \\
\text { price sacrifice }\end{array}$ & $\begin{array}{l}\text { Willingness } \\
\text { to pay more }\end{array}$ \\
\hline \multicolumn{7}{|l|}{ Warm Glow Path } \\
\hline Firm CSR engagement & $\rightarrow$ perceived CSR benefit & $.17^{\star \star}$ & $.17^{\star \star}$ & $.17^{\star *}$ & $.17^{\star \star}$ & $.17^{\star \star}$ \\
\hline Perceived CSR benefit & $\rightarrow$ dependent variable & $.08^{\star \star}$ & $.04^{\mathrm{n} . \mathrm{s}}$ & $.12^{\star *}$ & $-.03^{\text {n.s. }}$ & $.21^{\star *}$ \\
\hline \multicolumn{7}{|l|}{ Extra Charge Path } \\
\hline Firm CSR engagement & $\rightarrow$ perceived CSR price mark-up & $.04^{\text {n.s. }}$ & $.04^{\text {n.s. }}$ & $.04^{\text {n.s. }}$ & $.04^{\text {n.s. }}$ & $.04^{\text {n.s. }}$ \\
\hline Perceived CSR price mark-up & $\rightarrow$ dependent variable & $-.09 * *$ & $-.07^{\star \star}$ & $-.00^{\text {n.s. }}$ & $.20 * \star$ & $-.05^{\star}$ \\
\hline \multicolumn{7}{|l|}{ Interaction Effects } \\
\hline Perceived CSR benefit $\times$ intrinsic CSR attribution & $\rightarrow$ dependent variable & $.08^{\star \star}$ & $.07^{\star \star}$ & $.11^{\star \star}$ & $-.02^{\text {n.s. }}$ & $.06^{\star \star}$ \\
\hline Firm CSR engagement $\times$ intrinsic CSR attribution & $\rightarrow$ perceived CSR price mark-up & $-.11^{\star \star}$ & $-.11^{\star \star}$ & $-.11^{\star \star}$ & $-.11^{\star \star}$ & $-.11^{\star \star}$ \\
\hline \multicolumn{7}{|l|}{ Main Effects of Moderator } \\
\hline Intrinsic CSR attribution & $\rightarrow$ dependent variable & $.19 * \star$ & $.16^{\star \star}$ & $.16^{\star *}$ & $-.09 * \star$ & $.28 * \star$ \\
\hline Intrinsic CSR attribution & $\rightarrow$ perceived CSR price mark-up & $.02^{\text {n.s. }}$ & $.02^{\text {n.s. }}$ & $.02^{\text {n.s. }}$ & $.02^{\text {n.s. }}$ & $.02^{\text {n.s. }}$ \\
\hline \multicolumn{7}{|l|}{ Indirect Effects } \\
\hline \multicolumn{7}{|c|}{ Level of intrinsic CSR attribution: Low } \\
\hline \multicolumn{2}{|c|}{ Firm CSR engagement $\rightarrow$ perceived CSR benefit $\rightarrow$ dependent variable } & $.00^{\text {n.s. }}$ & $-.00^{\text {n.s. }}$ & $.01^{\text {n.s. }}$ & $-.00^{\text {n.s. }}$ & $.03^{\star *}$ \\
\hline \multicolumn{2}{|c|}{ Firm CSR engagement $\rightarrow$ perceived CSR price mark-up $\rightarrow$ dependent variable } & $-.01^{* *}$ & $-.01^{*}$ & $.00^{\text {n.s. }}$ & $.03^{\star *}$ & $\begin{array}{l}-.01^{\text {n.s. }} \\
(p=.056)\end{array}$ \\
\hline \multicolumn{7}{|c|}{ Level of intrinsic CSR attribution: High } \\
\hline \multicolumn{2}{|c|}{ Firm CSR engagement $\rightarrow$ perceived CSR benefit $\rightarrow$ dependent variable } & $.02^{* *}$ & $.02^{\star *}$ & $.03^{\star \star}$ & $-.01^{\text {n.s. }}$ & $.04^{\star \star}$ \\
\hline \multicolumn{2}{|c|}{ Firm CSR engagement $\rightarrow$ perceived CSR price mark-up $\rightarrow$ dependent variable } & $.00^{\text {n.s. }}$ & $.00^{\text {n.s. }}$ & $.00^{\text {n.s. }}$ & $-.01^{\text {n.s. }}$ & $.00^{\text {n.s. }}$ \\
\hline
\end{tabular}


TABLE 4

Study 3: Estimated Path Coefficients

\begin{tabular}{|c|c|c|c|}
\hline \multicolumn{2}{|l|}{ Path } & \multirow[t]{2}{*}{$\begin{array}{l}\text { Hypo- } \\
\text { thesis }\end{array}$} & \multirow[t]{2}{*}{$\begin{array}{l}\text { Estimated } \\
\text { Coefficient }\end{array}$} \\
\hline Main Effects CSR Engagement & & & \\
\hline Firm CSR engagement & $\rightarrow$ perceived level of firm CSR costs & & $.30 * \star$ \\
\hline Firm CSR engagement & $\rightarrow$ perceived price fairness & & $.02^{\text {n.s. }}$ \\
\hline \multicolumn{4}{|l|}{ Extra Charge Path } \\
\hline Perceived level of firm CSR costs & $\rightarrow$ perceived CSR price mark-up & & $.31^{\star \star}$ \\
\hline Perceived CSR price mark-up & $\rightarrow$ perceived price fairness & & $-.08^{\star}$ \\
\hline \multicolumn{4}{|l|}{ Warm Glow Path } \\
\hline Perceived level of firm CSR costs & $\rightarrow$ perceived CSR benefit & & $.41^{\star \star}$ \\
\hline Perceived CSR benefit & $\rightarrow$ perceived price fairness & & $.17^{\star \star}$ \\
\hline \multicolumn{4}{|l|}{ Main Effects of Moderators } \\
\hline Intrinsic CSR attribution & $\rightarrow$ promotional CSR cost type perception & & $-.09 *$ \\
\hline Philanthropic CSR engagement & $\rightarrow$ perceived level of firm CSR costs & & $-.10 \star$ \\
\hline Promotional CSR cost type perception & $\rightarrow$ perceived price fairness & & $-.10^{\star \star}$ \\
\hline Promotional CSR cost type perception & $\rightarrow$ perceived CSR price mark-up & & $.17^{\star \star}$ \\
\hline \multicolumn{4}{|l|}{ Interaction Effects } \\
\hline & $\mathrm{H}_{5}:+$ & $.17^{\star *}$ \\
\hline & $\times$ perceived level of firm CSR costs $\rightarrow$ perceived CSR price mark-up & & $.10^{*}$ \\
\hline \multicolumn{2}{|c|}{ Promotional CSR cost type perception $\times$ perceived CSR benefit $\rightarrow$ perceived price fairness } & & $-.12^{\star \star}$ \\
\hline \multicolumn{4}{|l|}{ Controlled Effects } \\
\hline Customer price knowledge & $\rightarrow$ perceived price fairness & & $-.28^{\star \star}$ \\
\hline General firm fairness image & $\rightarrow$ perceived price fairness & & $.49^{\star \star}$ \\
\hline Intrinsic CSR attribution & $\rightarrow$ perceived price fairness & & $.06^{\star}$ \\
\hline Philanthropic CSR engagement & $\rightarrow$ perceived price fairness & & $-.02^{\text {n.s. }}$ \\
\hline Firm CSR engagement & $\rightarrow$ perceived CSR benefit & & $.01^{\text {n.s. }}$ \\
\hline Intrinsic CSR attribution & $\rightarrow$ perceived CSR benefit & & $.10^{\star *}$ \\
\hline Firm CSR engagement & $\rightarrow$ perceived CSR price mark-up & & $.09 * *$ \\
\hline Intrinsic CSR attribution & $\rightarrow$ perceived CSR price mark-up & & $-.02^{\text {n.s. }}$ \\
\hline Perceived price fairness & $\rightarrow$ customer loyalty & & $.40^{\star *}$ \\
\hline Perceived CSR benefit & $\rightarrow$ customer loyalty & & $.42^{* *}$ \\
\hline \multicolumn{4}{|l|}{ Indirect Effects } \\
\hline \multicolumn{2}{|c|}{ Firm CSR engagement $\rightarrow$ perceived level of firm CSR costs $\rightarrow$ perceived CSR benefit } & $\mathrm{H}_{3}:+$ & $.12^{\star \star}$ \\
\hline \multicolumn{2}{|c|}{ Firm CSR engagement $\rightarrow$ perceived level of firm CSR costs $\rightarrow$ perceived CSR price mark-up } & $\mathrm{H}_{4}:+$ & $.09 * *$ \\
\hline \multicolumn{4}{|c|}{ Level of Promotional Cost Type Perception: Low } \\
\hline \multicolumn{2}{|c|}{ Firm CSR engagement $\rightarrow$ perceived level of firm CSR costs $\rightarrow$ perceived CSR benefit $\rightarrow$ perceived price fairness } & $\mathrm{H}_{6}:+$ & $.03^{\star *}$ \\
\hline \multicolumn{2}{|c|}{ Firm CSR engagement $\rightarrow$ perceived level of firm CSR costs $\rightarrow$ perceived CSR price mark-up $\rightarrow$ perceived price fairness } & & $.00^{\text {n.s. }}$ \\
\hline \multicolumn{4}{|c|}{ Level of Promotional Cost Type Perception: High } \\
\hline \multicolumn{2}{|c|}{ Firm CSR engagement $\rightarrow$ perceived level of firm CSR costs $\rightarrow$ perceived CSR benefit $\rightarrow$ perceived price fairness } & & $.01^{\text {n.s. }}$ \\
\hline \multicolumn{2}{|c|}{ Firm CSR engagement $\rightarrow$ perceived level of firm CSR costs $\rightarrow$ perceived CSR price mark-up $\rightarrow$ perceived price fairness } & $\mathrm{H}_{6}:-$ & $-.01 *$ \\
\hline
\end{tabular}

n.s. not significant, $p>.05,{ }^{\star} p<.05,{ }^{\star \star} p<.01$ (two-tailed); we report standardized coefficients. 


\section{APPENDIX: Measurement Scales}

\begin{tabular}{|c|c|c|c|}
\hline Construct & Definition & Measurement Items* & Source \\
\hline $\begin{array}{l}\text { Firm CSR } \\
\text { engagement } \\
\text { [Study } 1 \& 2 \text { ] }\end{array}$ & $\begin{array}{l}\text { Actions appearing to advance some } \\
\text { social good, beyond the interests of the } \\
\text { firm and beyond what is required by law }\end{array}$ & 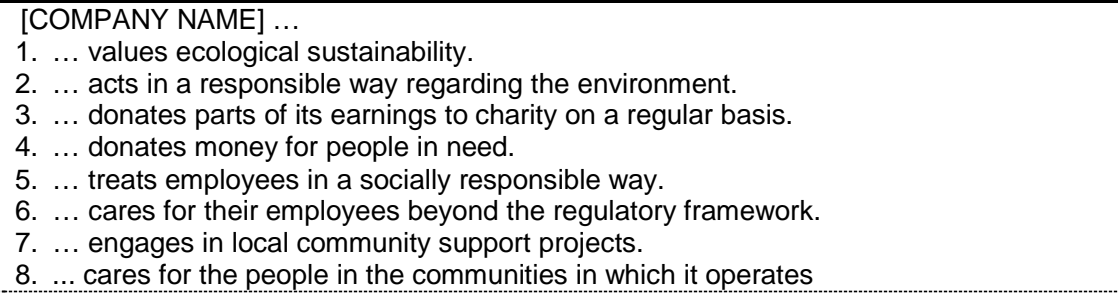 & $\begin{array}{l}\text { Lichtenstein, } \\
\text { Drumwright, and Braig } \\
\text { (2004); Luo and } \\
\text { Bhattacharya (2006); } \\
\text { McWilliams and Siegel } \\
\text { (2001); Sen and } \\
\text { Bhattacharya (2001); }\end{array}$ \\
\hline $\begin{array}{l}\text { Perceived price } \\
\text { fairness } \\
\text { [Study } 1]\end{array}$ & & The prices which [COMPANY NAME] charges are fair. & \multirow{2}{*}{$\begin{array}{l}\text { Bolton, Keh, and Alba } \\
\text { (2010); Campbell } \\
\text { (2007); Martin, Ponder } \\
\text { and Lueg (2009) }\end{array}$} \\
\hline $\begin{array}{l}\text { Perceived price } \\
\quad \text { fairness } \\
\text { [Study } 2,3 \& 4]\end{array}$ & A customer's evaluation of a price as just & $\begin{array}{l}\text { How do you evaluate [COMPANY NAME]'s prices? }{ }^{\text {d }} \\
\text { 1. unfair / fair } \\
\text { 2. not at all just / just } \\
\text { 3. unreasonable / reasonable } \\
\text { 4. inadequate / adequate }{ }^{c}\end{array}$ & \\
\hline $\begin{array}{l}\text { Perceived CSR } \\
\text { benefit } \\
\text { [Study } 2 \& 3]\end{array}$ & $\begin{array}{l}\text { A customer's perception of receiving } \\
\text { additional value from purchasing } \\
\text { products due to the CSR engagement of } \\
\text { a company }\end{array}$ & $\begin{array}{l}\text { 1. I derive benefit from supporting good causes by purchasing [COMPANY NAME] } \\
\text { products. } \\
\text { 2. After purchasing at [COMPANY NAME] I am satisfied as my money helps support the } \\
\text { good. } \\
\text { 3. I enjoy that [COMPANY NAME] uses my money to support the good. }\end{array}$ & Andrews et al. (2014) \\
\hline $\begin{array}{l}\text { Perceived CSR } \\
\text { price mark-up } \\
\text { [Study } 2 \text { \& 3] }\end{array}$ & $\begin{array}{l}\text { A customer's perception of elevated } \\
\text { product prices due to the CSR } \\
\text { investments of a company }\end{array}$ & $\begin{array}{l}\text { 1. I believe [COMPANY NAME]'s prices include a mark-up for the company's support of } \\
\text { good causes. } \\
\text { 2. I think [COMPANY NAME] has priced its corporate social responsibility activities into } \\
\text { its products. } \\
\text { 3. I think [COMPANY NAME] could reduce its prices if it didn't engage as much in } \\
\text { corporate social responsibility. }\end{array}$ & Own operationalization \\
\hline $\begin{array}{l}\text { Intrinsic CSR } \\
\text { attribution } \\
\text { [Study } 2,3 \& 4]\end{array}$ & $\begin{array}{l}\text { A customer's perception that a company } \\
\text { engages in CSR out of genuine concern }\end{array}$ & $\begin{array}{l}\text { 1. [COMPANY NAME] engages in charitable projects because it is genuinely concerned } \\
\text { about being socially responsible. } \\
\text { 2. I think that [COMPANY NAME] engages in its social projects due to altruistic motives. }{ }^{c} \\
\text { 3. I think [COMPANY NAME]'s social engagement results from an honest wish to do } \\
\text { good. }\end{array}$ & $\begin{array}{l}\text { Du, Bhattacharya, and } \\
\text { Sen (2007) }\end{array}$ \\
\hline $\begin{array}{l}\text { Customer loyalty } \\
\text { [Study } 1,3 \& 4]\end{array}$ & $\begin{array}{l}\text { A customer's commitment to repurchase } \\
\text { from or repatronize a vendor in the future }\end{array}$ & $\begin{array}{l}\text { It is very likely that I would ... } \\
\text { 1. ... purchase from [COMPANY NAME] in the future. } \\
\text { 2. ... recommend [COMPANY NAME] to friends. } \\
\text { 3. ... remain a customer if [COMPANY NAME] increased its prices. } \\
\text { 1. How likely is it that you will patronize [COMPANY NAME] again in the future? }{ }^{b} \\
\text { 2. How likely is it that you will recommend [COMPANY NAME] to a friend? } \\
\text { 3. I can say only positive things about [COMPANY NAME]. }\end{array}$ & $\begin{array}{l}\text { Homburg, Wieseke, } \\
\text { and Hoyer (2009) }\end{array}$ \\
\hline $\begin{array}{l}\text { Attitude toward } \\
\text { CSR } \\
\text { [Study 2] }\end{array}$ & $\begin{array}{l}\text { A customer's normative endorsement for } \\
\text { firms' social activities }\end{array}$ & $\begin{array}{l}\text { Companies should ... } \\
\text { 1. ... act in a responsible way regarding the environment. } \\
\text { 2. ... value ecological sustainability. } \\
\text { 3. ... regularly donate parts of their earnings for charity. } \\
\text { 4. ... donate products for people in need. } \\
\text { 5. ... treat their employees in a socially responsible way. } \\
6 . \ldots \text { care for their employees beyond the regulatory framework. } \\
\text { 7. ... engage in local community support projects in the communities in which they } \\
\text { operate. }\end{array}$ & $\begin{array}{l}\text { Lichtenstein, } \\
\text { Drumwright, and Braig } \\
\text { (2004); Mohr and } \\
\text { Webb (2005) }\end{array}$ \\
\hline
\end{tabular}




\begin{tabular}{|c|c|c|c|}
\hline $\begin{array}{l}\text { Perceived price- } \\
\text { value ratio } \\
\text { [Study 2] }\end{array}$ & $\begin{array}{l}\text { A customer's perception of the degree to } \\
\text { which a company's product performance } \\
\text { and product prices are in balance }\end{array}$ & $\begin{array}{l}\text { Products of }[\text { COMPANY NAME] } \ldots \\
1 . \ldots \text { have a very poor price-value ratio } / \ldots \text { have a very high price-value ratio } \\
2 . \ldots \text { do not offer value for money } / \ldots \text { offer value for money } \\
\text { 3. .... are not good products for their prices } / \ldots \text { are good products for their prices }\end{array}$ & $\begin{array}{l}\text { Sweeney and Soutar } \\
\text { (2001) }\end{array}$ \\
\hline $\begin{array}{l}\text { Perceived } \\
\text { quality } \\
\text { [Study 2] }\end{array}$ & $\begin{array}{l}\text { A customer's perception of the degree of } \\
\text { a company's product performance }\end{array}$ & $\begin{array}{l}\text { Products of [COMPANY NAME] } \ldots \\
1 . \ldots \text { have very poor quality } / \ldots \text { have very high quality } \\
\text { 2. } \ldots \text { are inferior } / \ldots \text { are superior } \\
\text { 3. } \ldots \text { are poorly made } / \ldots \text { are well made }\end{array}$ & $\begin{array}{l}\text { Sweeney and Soutar } \\
\text { (2001) }\end{array}$ \\
\hline $\begin{array}{l}\text { Perceived price } \\
\text { sacrifice } \\
\text { [Study 2] }\end{array}$ & $\begin{array}{l}\text { A customer's perception of a company's } \\
\text { price level }\end{array}$ & $\begin{array}{l}\text { 1. [COMPANY NAME] has very high prices. } \\
\text { 2. Products of [COMPANY NAME] are very expensive }\end{array}$ & $\begin{array}{l}\text { Bornemann and } \\
\text { Homburg (2011) }\end{array}$ \\
\hline $\begin{array}{l}\text { Willingness to } \\
\text { pay more } \\
\text { [Study 2] }\end{array}$ & $\begin{array}{l}\text { A customer's willingness to remain a } \\
\text { customer of a company in case of an } \\
\text { increase of the company's price level } \\
\text { relative to other companies }\end{array}$ & $\begin{array}{l}\text { 1. I am willing to pay a higher price at [COMPANY NAME] than at its competitors. } \\
\text { 2. I would like to keep buying at [COMPANY NAME], even if other companies were } \\
\text { cheaper. } \\
\text { 3. For the advantages I have as a customer of [COMPANY NAME] I would be willing to } \\
\text { pay a higher price. }\end{array}$ & $\begin{array}{l}\text { Zeithaml, Berry, and } \\
\text { Parasuraman (1996) }\end{array}$ \\
\hline $\begin{array}{l}\text { Perceived level } \\
\text { of firm CSR } \\
\text { costs } \\
\text { [Study 3] }\end{array}$ & $\begin{array}{l}\text { A customer's subjective perception of the } \\
\text { amount of money that a firm invests in } \\
\text { social activities }\end{array}$ & $\begin{array}{l}\text { 1. PowerMart bears considerable costs for its social activities. } \\
\text { 2. The amount of money that PowerMart invests for its social projects is very large. } \\
\text { 3. PowertMart incurs very high costs for its social engagement. }\end{array}$ & Kirmani $(1990,1997)$ \\
\hline $\begin{array}{l}\text { Promotional } \\
\text { CSR cost type } \\
\text { perception } \\
\text { [Study 3] }\end{array}$ & $\begin{array}{l}\text { The extent to which a customer } \\
\text { perceives a firm's CSR spendings as } \\
\text { self-serving to promote its image }\end{array}$ & $\begin{array}{l}\text { 1. I regard PowerMart's costs for its social activities as costs to improve its image. } \\
\text { 2. I regard PowerMart's costs for its social activities as costs to improve its public } \\
\text { reputation. } \\
\text { 3. I regard PowerMart's costs for its social activities as costs to improve its standing. }\end{array}$ & Kirmani $(1990,1997)$ \\
\hline $\begin{array}{l}\text { General fairness } \\
\text { image } \\
\text { [Study 3] }\end{array}$ & $\begin{array}{l}\text { A customer's perception of a firm's } \\
\text { general disposition towards achieving } \\
\text { equitable exchange relationships with its } \\
\text { stakeholders }\end{array}$ & $\begin{array}{l}\text { 1. PowerMart is a just company. } \\
\text { 2. PowerMart treats its customers in fair way. } \\
\text { 3. PowerMart appears just to me. }\end{array}$ & $\begin{array}{l}\text { Bolton, Keh, and Alba } \\
\text { (2010) }\end{array}$ \\
\hline $\begin{array}{l}\text { Customer price } \\
\text { knowledge } \\
\text { (reverse coded) } \\
\text { [Study 3] }\end{array}$ & $\begin{array}{l}\text { The extent to which a customer is } \\
\text { familiar with regular price levels for a } \\
\text { specific product }\end{array}$ & $\begin{array}{l}\text { 1. I am not familiar with regular price levels for external hard drives. } \\
\text { 2. I do not know what one usually has to pay for an external hard drive. } \\
\text { 3. I do not know what an adequate price level for an external hard drive would be. }\end{array}$ & $\begin{array}{l}\text { Lichtenstein, Ridgway, } \\
\text { and Netemeyer (1993) }\end{array}$ \\
\hline $\begin{array}{c}\text { Firm CSR } \\
\text { engagement } \\
\text { (manipulation } \\
\text { check) } \\
{[\text { Study 3] }}\end{array}$ & $\begin{array}{l}\text { A customer's perception whether a firm } \\
\text { adheres to high standards of social and } \\
\text { ethical obligations }\end{array}$ & $\begin{array}{l}\text { 1. PowerMart is a company that acts socially responsible. } \\
\text { 2. PowerMart cares for the well-being of society. } \\
\text { 3. PowerMart holds high ethical standards. }\end{array}$ & $\begin{array}{l}\text { Du, Bhattacharya, and } \\
\text { Sen (2007) }\end{array}$ \\
\hline $\begin{array}{l}\text { CSR type } \\
\text { (manipulation } \\
\text { check) } \\
\text { [Study 3] }\end{array}$ & $\begin{array}{l}\text { Focus of a firm's CSR either on } \\
\text { business process or philanthropic CSR }\end{array}$ & $\begin{array}{l}\text { The social engagement of PowerMart focuses on ... } \\
1 . . . . \text { the sustainability of its processes } / \ldots \text { helping people in need }\end{array}$ & Own operationalization \\
\hline $\begin{array}{l}\text { CSR budget } \\
\text { source } \\
\text { (manipulation } \\
\text { check) } \\
\text { [Study } 4]\end{array}$ & $\begin{array}{l}\text { A customer's perception of where the } \\
\text { funding of CSR engagement originates }\end{array}$ & $\begin{array}{l}\text { YourStyle's expenses for CSR engagement ... } \\
\text { 1. ... pay for themselves through additional revenue. } \\
\text { 2. ... are financed from YourStyles's advertising budget. } \\
\text { 3. ... are financed by reducing executive salaries. } \\
\text { 4. ... are financed from YourStyle's profit. }\end{array}$ & Own operationalization \\
\hline
\end{tabular}
[Study 4] 4. .... are financed from YourStyle's profit.

All items are measured on seven-point Likert scales anchored "fully disagree" to "fully agree" unless indicated otherwise.

${ }^{a}$ measured on seven-point differential, ${ }^{\text {b }}$ anchored "very unlikely" to "very likely." c Addition in Study 3 and Study $4,{ }^{d}$ In Study 3 and 4 a specific price was provided (see study description). 